\title{
Bioactive Molecules Derived from Snake Venoms with Therapeutic Potential for the Treatment of Thrombo-Cardiovascular Disorders Associated with COVID-19
}

\author{
Fatah Chérifi $^{1} \cdot$ Fatima Laraba-Djebari $^{1}$ (D) \\ Accepted: 24 August 2021 / Published online: 9 September 2021 \\ (c) The Author(s), under exclusive licence to Springer Science+Business Media, LLC, part of Springer Nature 2021
}

\begin{abstract}
As expected, several new variants of Severe Acute Respiratory Syndrome-CoronaVirus-2 (SARS-CoV-2) emerged and have been detected around the world throughout this Coronavirus Disease of 2019 (COVID-19) pandemic. Currently, there is no specific developed drug against COVID-19 and the challenge of developing effective antiviral strategies based on natural agents with different mechanisms of action becomes an urgent need and requires identification of genetic differences among variants. Such data is used to improve therapeutics to combat SARS-CoV-2 variants. Nature is known to offer many biotherapeutics from animal venoms, algae and plant that have been historically used in traditional medicine. Among these bioresources, snake venom displays many bioactivities of interest such as antiviral, antiplatelet, antithrombotic, antiinflammatory, antimicrobial and antitumoral. COVID-19 is a viral respiratory sickness due to SARS-CoV-2 which induces thrombotic disorders due to cytokine storm, platelet hyperactivation and endothelial dysfunction. This review aims to: (1) present an overview on the infection, the developed thrombo-inflammatory responses and mechanisms of induced thrombosis of COVID-19 compared to other similar pathogenesis; (2) underline the role of natural compounds such as anticoagulant, antiplatelet and thrombolytic agents; (3) investigate the management of coagulopathy related to COVID-19 and provide insight on therapeutic such as venom compounds. We also summarize the updated advances on antiviral proteins and peptides derived from snake venoms that could weaken coagulopathy characterizing COVID-19.
\end{abstract}

Fatima Laraba-Djebari

flaraba@usthb.dz; flaraba@hotmail.com

1 USTHB, Faculty of Biological Sciences, Laboratory of Cellular and Molecular Biology, USTHB, BP 32,

El-Alia, Bab Ezzouar, Algiers, Algeria 


\section{Graphic Abstract}

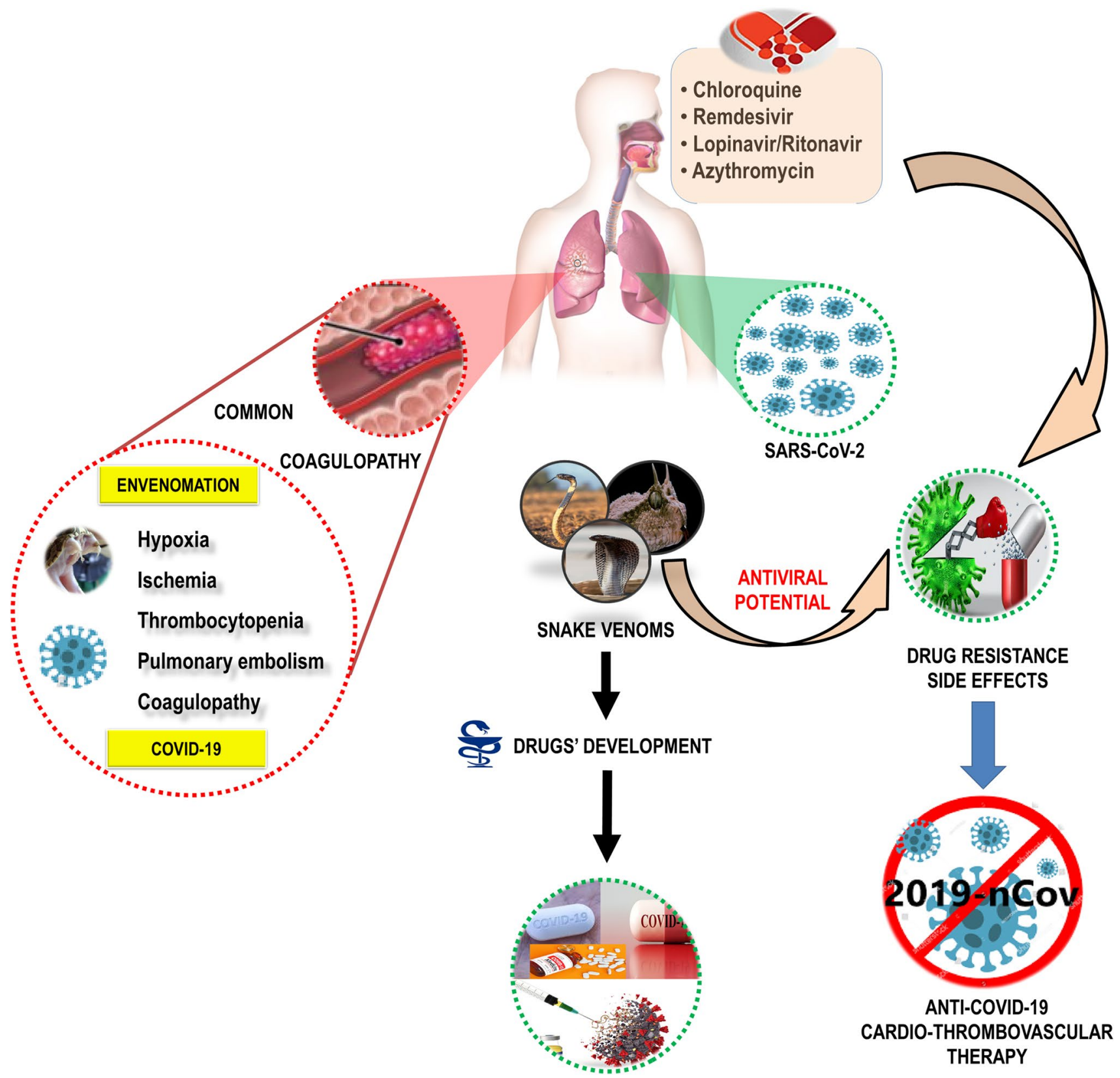

Keywords SARS-CoV-2 variants $\cdot$ COVID-19 $\cdot$ Snake venoms $\cdot$ Coagulopathy $\cdot$ Antiplatelet peptides $\cdot$ Antithrombotic compounds

Abbreviations

ACE-2

ACE-2R

Angiotensin Converting Enzyme-2

ACh Esterases

ADAMTS13

Ang

Acetyl choline esterases. thrombospondin type 1 repeats- 13 .

Angiotensin
aPTT

ARDS

A disintegrin and metalloprotease with
BBPs

BPTI

COVID-19

CRISPs
The activated partial thromboplastin time.

Acute Respiratory Distress Syndrome Bradykinin Blocker Peptides

Inhibitors of bovine pancreatic trypsin CoronaVirus Disease of 2019

Cysteine-Rich Secretory Proteins 


\begin{tabular}{|c|c|}
\hline CRP & C-reactive protein \\
\hline CXCL4 & Platelet factor 4 \\
\hline CXCL7 & Peptide- 2 activating neutrophils \\
\hline DD & D-Dimers. \\
\hline DENV & The dengue virus \\
\hline $\mathrm{DIC}$ & Disseminated intravascular coagulation. \\
\hline DVT & Deep vein thrombosis \\
\hline $\mathrm{E}$ & Envelope \\
\hline $\mathrm{EC}$ & Endothelial cells. \\
\hline ECs & Endothelial cells \\
\hline eNOS & Endothelial Nitric Oxide Synthase \\
\hline FIB & Fibrinopeptide. \\
\hline G-CSF & Granulocyte colony-stimulating factor \\
\hline $\mathrm{HCoV}$ & Human CoronaVirus \\
\hline HK & High molecular weight kininogen \\
\hline INR & The standardized international report \\
\hline IP-10 & $\begin{array}{l}\text { The human interferon-inducible protein } \\
10 .\end{array}$ \\
\hline KHPM & $\begin{array}{l}\text { Prekallikrein, complexed with high } \\
\text { molecular weight kininogen }\end{array}$ \\
\hline KKS & Kinin-Kallikrein System \\
\hline LAAO & L-Amino acid oxidases \\
\hline LMWH & Low molecular weight heparins \\
\hline MCP-1 & Chemoattractant Protein-1 monocyte \\
\hline MERS-CoV & "Middle East Respiratory Syndrome \\
\hline MIP & Macrophage Inflammatory Proteins \\
\hline NETs & Extracellular neutrophils traps \\
\hline NGF & Nerve Growth Factor \\
\hline NO & Nitric Oxide \\
\hline ORF & Open reading frame \\
\hline PAI-1 & The plasminogen activator inhibitor. \\
\hline PAR & Receptors activated by proteinases \\
\hline PE & Pulmonary embolism. \\
\hline PL & Phospholipids \\
\hline PLA2 & Phospholipases A2 \\
\hline PMN & Polymorphonuclear cell \\
\hline PPK & Plasma prekallikrein \\
\hline PT & Prothrombin time \\
\hline PTT & Thrombotic thrombocytopenic purpura \\
\hline QT & Quick time. \\
\hline $\mathrm{S} 1 / \mathrm{S} 2$ & Subunits 1 and 2 \\
\hline \multirow[t]{2}{*}{ SARS-CoV-2 } & Severe Acute Respiratory \\
\hline & Syndrome-CoronaVirus-2 \\
\hline SV-LAAOs & Snake Venom L-Amino Acid Oxidases \\
\hline SVMPs & Snake Venom Metalloproteinases \\
\hline SV-PLA2s & Snake Venom Phospholipases A2 \\
\hline SVSPs & Snake Venom Serine proteinases \\
\hline $\mathrm{TF}$ & Tissue factor. \\
\hline TLR & Toll-like receptors \\
\hline TMPRSS2 & Transmembrane protease, serine 2 \\
\hline TT & Thrombin time. \\
\hline VEGF & Vascular Endothelial Growth Factor \\
\hline VWF & Von Willebrand factor \\
\hline
\end{tabular}

WHO World Health Organization. YFV Yellow Fever Virus

\section{Introduction}

Since the beginning of 2020 to the present day, the COVID19 has been spreading in all the countries throughout the world. Besides the various vaccines being offered to prevent this pandemic there is still no alternative treatment such as drugs that could alleviate the pathophysiological complications caused by SARS-CoV-2. For this purpose, the use of natural sources including snake venoms and their pharmacological components could help identify a treatment for COVID-19. There are no efficient and specific therapies to treat the COVID-19, even if a number of therapeutic approaches have been proposed to combat this pandemic [1-3]. The used repurposed drugs such as chloroquine and remdesivir are able to attenuate some symptoms of this infection. Both have shown efficiency to attenuate some symptoms of COVID-19. Some reports of preclinical trials revealed that the antiplatelet activity of hydroxychloroquine can cause the production of thromboxane A2 and lead to a decrease in fibrinogen levels through its interaction with the arachidonic acid (AA) pathway [3]. Remdesivir, a RNA polymerase inhibitor of SARS-CoV-2, is a nucleoside analog that targets viral replication enzymes during viral replication which results in deadly mutations [4]. Remdesivir has good efficacy against a broad-spectrum of viruses (SARS-CoV, MERS-CoV and SARS-CoV-2) and reduces the time to recovery of hospitalized patients who require supplemental oxygen. Remdesivir may have a positive impact on mortality outcomes while having a favorable safety profile [5]. Although this is an important milestone in the fight against COVID-19, approval of this drug will not be sufficient to solve the public health issues caused by the ongoing pandemic. Further scientific efforts are needed to evaluate the full potential of nucleoside analogs as treatment or prophylaxis of viral respiratory infections and to develop effective antivirals that are orally bioavailable [5].

While it is not unusual for infections to raise the risk of clotting, an unprecedented range of clotting-related disorders have been observed in patients infected with SARS-CoV-2 [6].

From benign skin lesions on the feet to life-threatening thrombotic events, infection by SARS-CoV-2 leads to high prevalence of deadly blood clots [7]. Searching for natural and safe therapeutics that restrain platelet functions and inhibit risk-free plasma factors would be an interesting goal to identify new therapeutic approaches (Fig. 1). For adequate and therapeutic management of COVID-19 coagulopathy, it would be of interest to resort towards natural molecules without side-effects [8]. 


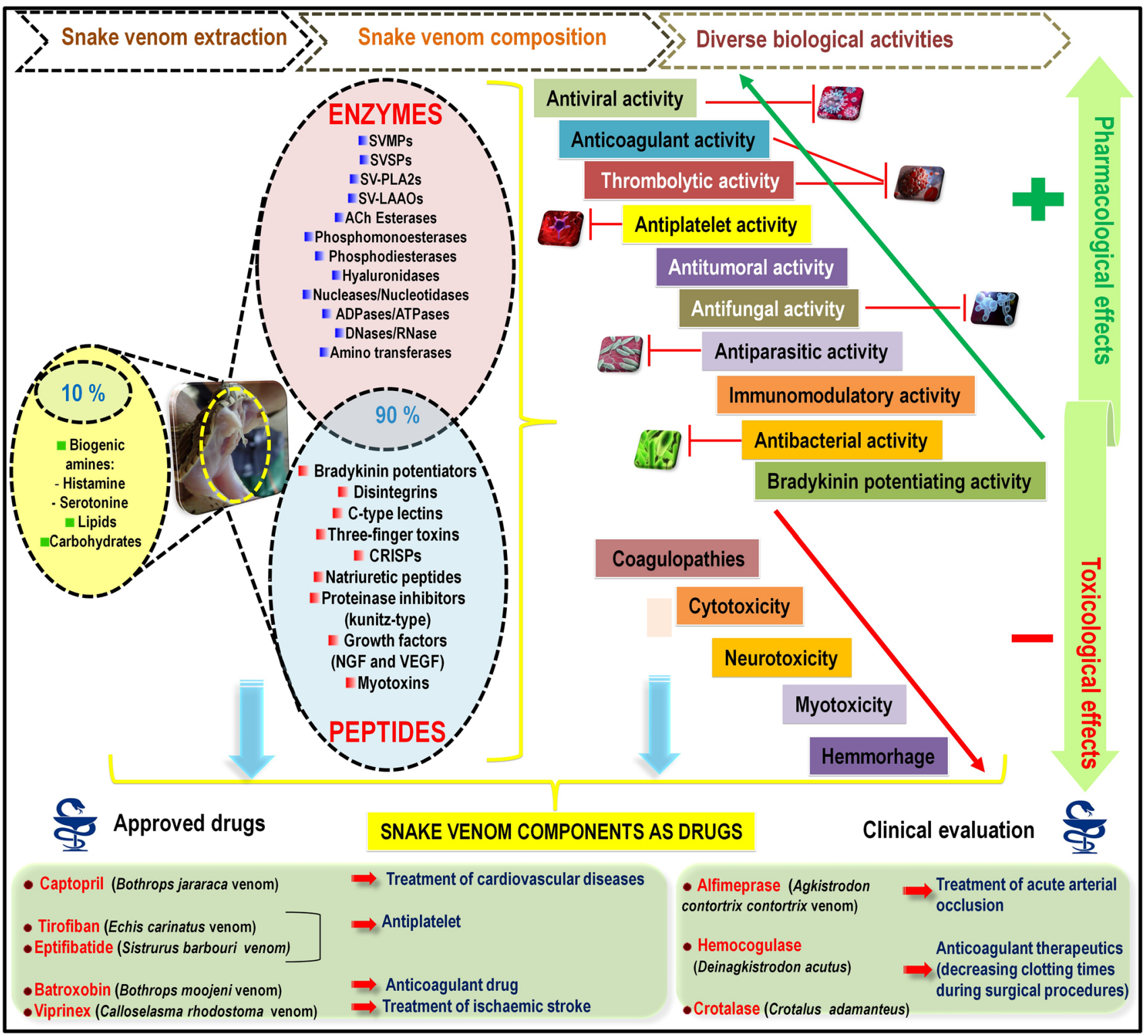

Fig. 1 Snake venom composition, biological activities and snake venom derived-compounds as drugs [11-25] (ACh Esterases acetyl choline esterases, SVMPs snake venom metalloproteinases, SVSPS Snake Venom Serine proteinases, SV-PLA2s Snake venom phospho- lipases A2, SV-LAAOs snake venom L-amino acid oxidases, CRISPs cysteine-rich secretory proteins, $N G F$ nerve growth factor, $V E G F$ vascular endothelial growth factor)
Natural components isolated from snake venoms could be a promising alternative given their beneficial pharmacology. Thus, this current review aims to: i) describe some data related to coagulopathies of COVID-19 and snakebite envenomation; ii) provide proven examples of anti-clotting and/or antiplatelet polypeptides derived from snake venoms as potential safe candidate drugs.

\section{Usefulness of Snake Venoms and Their Components in the Management of COVID-19 Pathogenesis}

Despite the newly developed vaccines against COVID-19, it is important to find additional solutions to fight against infection with SARS-CoV-2. Snake venoms and their components could be a promising alternative given their variety. These components remain highly relevant for use as experimental tools to elucidate several physiological 
mechanisms given their selective modes of action. In addition, snake venom derived-compounds can serve as good drugs for developing new biotherapeutics and diagnostics with relevant biomedical applications for many human diseases. Such isolated snake venoms-derived compounds have long been known to possess medicinal and pharmacological properties [9]. Many of them could be used as antithrombotic [10], antiplatelet [11], antibacterial [12], antifungal [13], antiparasitic [14], anti-inflammatory drugs, and interestingly, as potential antiviral against several viral diseases (Fig. 1). Some of these therapeutic applications inherent to compounds derived from snake venoms will be described throughout this review; a particular attention will be given to antithrombotic compounds in relation to SARS-CoV-2 coagulopathy.

With regards to COVID-19 pandemic, some primary care physicians reported that the pathogenesis of COVID-19 brought about by SARS-CoV-2 is initiated by a high hypoxemia in vasculatures and leads to ARDS (Acute Respiratory Distress Syndrome). Collapsed lungs due to many blocked veins by micro-embolism are believed to be the final cause of death for many infected individuals [26].

Coagulopathy corresponds to various disorders causing either hemorrhages or excess coagulation responsible for the formation of clots in the arteries [27]. These disorders can be serious in the case of a simple slowdown in coagulation [28]. Weak hemorrhages may occur spontaneously revealing more serious disorders which may lead to massive bleeding depending on the site and the extent of the bleeding [29, 30]. The hemostatic disorders could be related either to the structural or functional abnormalities of coagulation factors themselves, or either to their deficiencies [21, 31, 32]. The excess of coagulation causing thrombosis is reported after snakebites and also for COVID-19 due to increased concentration of coagulation factors or hyperactivation of platelets. A disturbance of hemostasis on endothelial cells, platelet functions and on various plasma and tissue factors results in an imbalance between their activation and inactivation.

Several molecules from various animal sources, in particular from snake (Viperidae and Crotalidae) venoms are known to substitute the plasma factors or to interact on the platelet function thus making a possible correction of coagulopathy.

\section{SARS-CoV-2 and its New Variants: Infection and Transmission}

\section{1 $\beta$-Coronaviruses and SARS-CoV-2 Outbreak}

SARS-CoV-2, similar to other beta-Coronaviruses, is a causative pathogen of a severely contagious infection that can be quickly transmitted via various modes such as through the ingestion of virus loaded-droplets or their direct inhalation through sneezes and coughs. Viral infection also can be spread by spontaneous touch upon contact with contaminated surfaces (https://www.who.int/health-topics/coronavirus\#tab=tab_3) $[33,34]$.

During the decade of 2002-2012, SARS-CoV and MERS-CoV (Middle-East respiratory syndrome coronavirus) were the two earlier coronaviruses to appear in Asia where they spread and caused fatal pneumonia associated with thromboembolic abnormalities in severely affected patients [35-37] (Fig. 2A):

- Guangdong (province of China) was in 2002, the first city of contamination emerged by SARS-CoV where a cluster was formed leading to the infection of 8,098 people and causing around 774 victims in the world through human air routes $[35,36]$.

- The second coronavirus; MERS-CoV was discovered for the first time in the region of the Arabian Peninsula which was the origin of its strong and rapid spread to other countries (27) where it maintains its high virulence and is considered to be a general real medical condition since 2012. In fact, infected cases with MERS-CoV with 2,494 individuals of which 858 have died [37].

- SARS-CoV-2 was identified in December 2019 where it was found in the Chinese city of Wuhan [38, 39]. Zhu and collaborators have isolated the virus and sequenced it entire genomic RNA in January 2020 [40].

The pandemic of COVID-19 resulting from SARS-CoV-2 infection was characterized by an ongoing outbreak of severe pneumonia accompanied with serious coagulopathy [38, 39]. On January 30th, 2020, the World Health Organization (WHO) has recognized this infectious and deadly disease as a global medical emergency. WHO reported on August 2, 2021 198,022,041 positive infected people and 4,223,460 from whom have died (https://covid19.who.int/) [41]. Further, speeding up of the rate of new cases is more prominent in the European region. Globally, a substantial rise in deaths was likewise accounted with the Delta variant [42].

In Algeria, COVID-19 pandemic has negatively impacted all sectors. According to updated daily reports published by WHO recorded 171392 confirmed cases of infection including 4254 deaths on August 2nd, 2021 (https://www.who.int/ countries/dza/) [41].

\subsection{SARS-CoV-2 Structure, Replication Cycle and ACE-2 Down Regulation}

As one of the seven $\beta$-Coronaviruses, SARS-CoV-2 consists of a single-stranded RNA virus comprised of $\sim 30 \mathrm{~kb}$ nucleotides encoding for its proteome including various catalytically active proteins which exhibit crucial roles at 


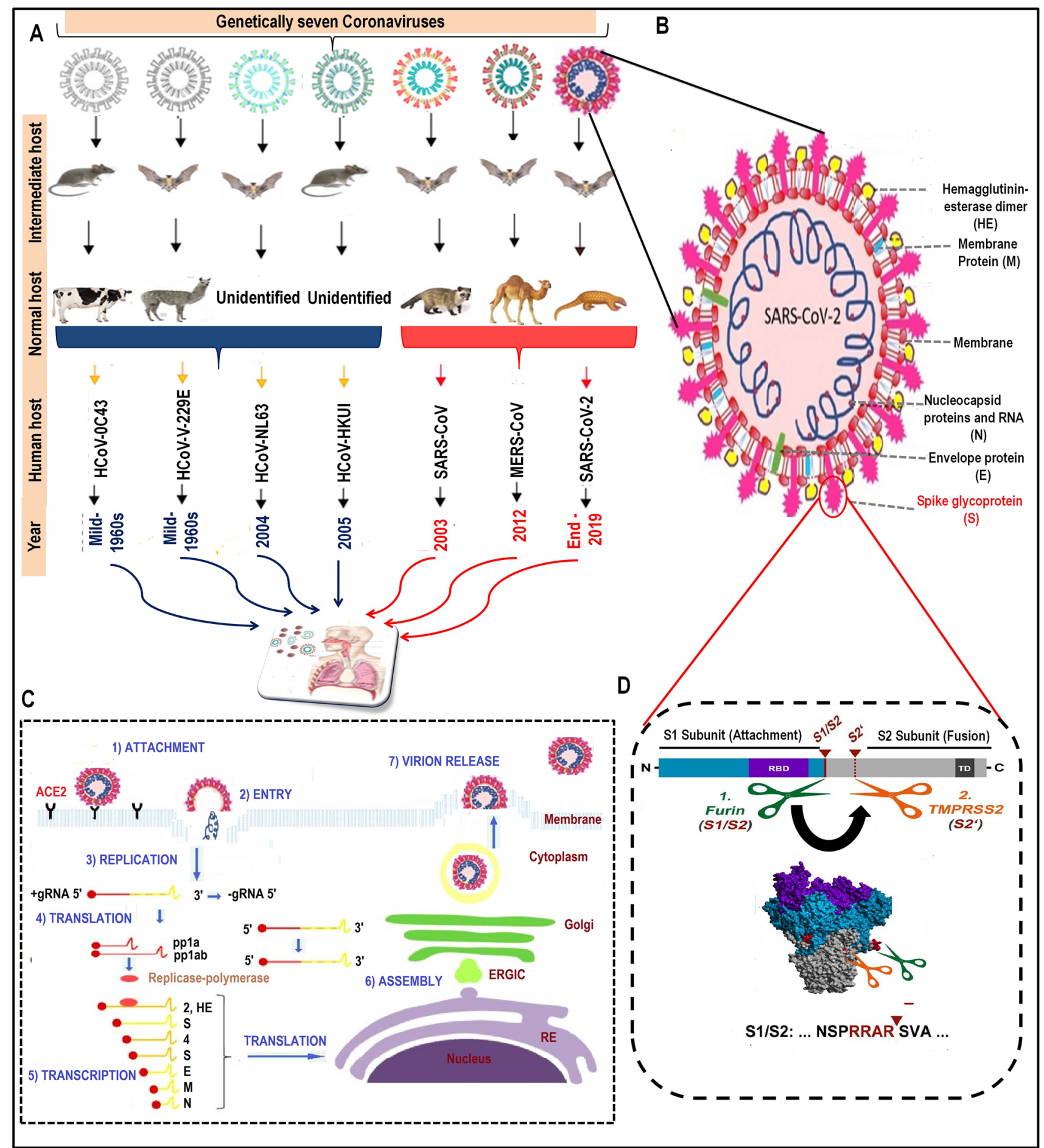

Fig. 2 Overview on coronaviruses outbreak. A Origin and transmission of genetically pathogenic HCoVs. B Schematic structure of SARS-CoV-2. C SARS-CoV-2 replicative cycle. D The structure organization and cleavage of Spike protein into domains S1 and S2 for COVID-19 [35, 36, 38, 39, 49] many stages of viral infection (Fig. 2B). SARS-CoV-2 interacts with the receptor of the angiotensin converting enzyme (ACE-2) receptor in order to internalize into host-cells particularly in the pulmonary alveoli and the vascular endothelium, which both richly express this receptor [43]. Additionally, ACE is a zinc metalloproteinase found in many 
other types of cells and tissues including heart, liver, kidneys, testicles and digestive organs [44]. SARS-CoV-2 infection, particularly in ARDS arrays, seems to be significantly correlated to numerous events of hemostatic disorders.

Many groups of researchers reported that SARS-CoV and SARS-CoV-2 shared close sequence similarities [38, $45,46]$. Nonetheless, according to Wang and collaborators [47], the zoonotic transmission of SARS-CoV is mediated by two normal hosts (palm civets and racoon dogs) [47]. SARS-CoV, MERS-CoV and SARS-CoV-2 are the highest virulent $\beta$-coronaviruses whilst HCoV-HKU1, HCoV-OC43, HCoV-229E and HCoV-NL63 are pathogens characterized by a low-pathogenicity but remain endemic in individuals (Fig. 2A and 2B) [48]. From today, there are several efforts to develop vaccine formulations to combat COVID-19; some of them are used.

SARS-CoV-2 expresses four structural proteins Spike (S) protein, Membrane (M) protein, Envelope (E) protein and Nucleocapsid (N) protein that are altogether closely implicated in keeping up enhanced viral infection destructiveness. Therefore, they play a crucial role for maintaining enhanced virus virulence. The role of each protein of SARS-CoV-2 during virus replicative cycle is illustrated in Fig. 2B and $2 \mathrm{C}$.

The Spike protein is the main structural protein that stretches along the surface of the virus [49]. Spike protein exhibits double roles during the cycle of SARS-CoV-2 replication: i) the virus attachment to ACE-2 receptor on the host cell, and in $i i)$ the viral entry into the host cell by prompting the fusion between their respective membranes.

The full 3-dimensional structure of the S-protein was elucidated as a glycoprotein made of three indistinguishable chains (1273 amino acid residues) and including two domains named S1 and S2 subunits [50] (Fig. 2D). The S1 and S2 subunits allow S-protein to bind to ACE-2 receptor and facilitate fusion viral and host cell membranes respectively [40].

The M-protein is responsible for the assembly of SARSCoV-2 whilst the N-protein covers the viral genomic RNA and assumes its replication and transcription. The binding of N-protein to genomic RNA virions through its N-terminal domain processes the replication and translation of SARS-CoV-2 [51]. Currently, a few studies in progress are focusing on this phase of the SARS-CoV-2 replication cycle to develop effective drugs that could successfully prevent contact between the RNA strand of SARS-CoV-2 and the $\mathrm{N}$-terminal of the N-protein [52].

Several reports revealed that E-protein which is known to be responsible for the virions' assembly, presents other roles in infection since it is involved in stress response of the host cell [53, 54].

During the process of infection, SARS-COV-2 downregulates ACE-2 as it attaches to ACE-2 receptor (ACE-2R)
[55]. The transmembrane protease serine-2 (TMPRSS2) is responsible for mediating virus entry through in COVID-19 sickness [40]. The involvement of kinin-kallikrein system (KKS) during COVID-19 disease is evidenced by Cathepsin $\mathrm{L}$ which upgrades KKS and regulates bradykinin concentrations. These events may be, in part, promising for possible therapies of this pathogenesis [56].

The Acute Respiratory Distress Syndrome (ARDS) is initiated through the down regulation of ACE-2 expression once SARS-COV-2 attaches to ACE-2R. Subsequently, ARDS was induced by an increase of angiotensin II (Ang II) correlated at the same time to angiotensin 1-7 decrease [57]. It has been reported that induced ARDS by SARSCoV-2 may be prevented when angiotensin 1-7 effects are enhanced [58]. In addition, both endothelial nitric oxide synthase (eNOS) suppression and the decrease of nitric oxide (NO) are associated with COVID-19 sickness and both events enhance endothelial dysfunction, that prompts thrombotic events and organ failure [59,60]. Thrombotic events related to endothelial dysfunction are fully discussed in following section.

\subsection{New SARS-CoV-2 Variants}

At the end of 2020, some countries including United Kingdom (UK), United States (USA), South Africa, Brazil and India have reported the emergence of multiple variants of SARS-CoV-2. Identified variants showed one or more mutations that have undergone in the genomic RNA of the wildtype virus that differentiate them from each other:

- B.1.1.7: This variant first detected in the US at the end of December 2020. Genetic investigations revealed that this variant carries at least seven mutations (69/70 deletion, 144Y deletion, N501Y, A570D, D614G, P681H) [61]. This variant was emerged in UK in January 2021 where it caused increased risk of death compared with other variants.

- B.1.351: A new variant of SARS-CoV-2 known as B.1.351 emerged in South Africa. The first detected cases of B.1.351 were reported in the US at the end of January 2021. According to (https://www.niid.go.jp/niid/en/2019ncov-e/10108-covid19-33-en.htmlexternal icon) [62], the Moderna mRNA-1273 vaccine currently used in the US may be less effective against B.1.351 but this speculation needs more scientific investigations.

- P.1: P.1 is another new variant SARS-CoV-2 that has been identified in Brazil and US at the end of January $2021^{\circ}$ The P.1 carries of about seventeen mutations (including K417T, E484K, and N501Y) that target the receptor binding domain of the spike protein [63]. Zhou and collaborators (2021) [64] suggest that these several mutations might disturb the recognition of the 
virus by antibodies released after vaccination with the wild-type SARS-CoV-2.

All these variants shared a specific mutation (D614G) in the amino acid sequence of spike protein that gives them the ability to spread more quickly than viruses without the mutation [65].

At the present time, the expert group convened by WHO has recommended using letters of the Greek Alphabet, i.e., Alpha, Beta, Gamma, Delta which will be easier and more practical to discussed by non-scientific audiences The variant Delta, also known as B.1.617.2, was earliest documented in India on October 2020. WHO has considered this variant of concerns (VOC) on May 11, 2021. This VOC shows evidence of increased transmission and more severe disease (https://www.who.int/en/activities/tracking-SARS-CoV-2variants/) [66]. The Delta variant can spread more easily and the strain has mutations on the spike protein that make it easier for it to infect human cells. That means people may be more contagious if they contract the virus and more easily spread it to others. It is now the dominant strain in the world.

\section{Thromboembolic disorders in severe COVID-19 compared to that induced after snake envenomation}

\subsection{Coagulopathy in snake envenomation}

Snake envenoming is a real health problem and economic burden in many regions around the world. It was recognized by WHO as neglected tropical diseases of priority because they affect people under 30 years old $[67,68]$. According to Kasturiratne and collaborators [69], the estimated burden of snake bite is $\sim 1.8-2.7$ million cases of bitten individuals and 81,410-137,880 deaths occur every year around the world $[70,71]$.

Snake venoms are very complex when compared to those of spider or scorpion venoms [72]. They are a rich source of a variety of proteins, and peptides endowed with several pharmacological potentials. The beneficial effects of venom derived components are attributed to disulfide bridged peptides. Snake venom composition is an unpredictable complex combination of 50-200 pharmacologically-active proteins and peptides distributed in major and minor groups [21, 22] (Fig. 1). Therefore, the major groups are snake venom serine proteases (SVSPs), snake venom metalloproteinases (SVMPs), secreted phospholipases $\mathrm{A}_{2}$ (SV-PLA2s), C-type lectins and disintegrins, while the secondary families comprise nucleotidases (Ntases), phosphodiesterases (PDEs), cysteine-rich secretory proteins, L-amino acid oxidases, Kunitz peptides, three-finger peptides (3FTX) and natriuretic peptides [20-23, 25].
Most of snake venom family components may act at several stages on coagulation system which is considered as the main impaired process after snakebite envenoming [9, 73]. These diverse compounds can cause hemorrhage through various manners. They are good agents at $(i)$ damaging endothelial cells as well as disturbing their interactions with the basement membrane, (ii) upsetting platelet aggregation which is crucial for blood clotting, (iii) impairing the blood coagulation cascade by activating blood coagulation or (iv) potentially repressing the blood coagulation cascade [74]. These components are also able to cleave fibrinogen and dissolve the already formed blood clots [74]. These effects explain the disturbance of hemostasis as serious consequences of snakebites. These coagulopathy disorders could be compared to those reported in SARS-CoV-2 infection. Furthermore, many reports highlighted the importance of coagulopathies after snake envenomation which is tightly associated with cardiovascular effects and endothelial dysfunction that are similar to those seen in severe COVID-19. Therefore, many same characteristics are found common between snake envenomations and SARS-CoV-2 pandemic that may help to understand the several thromboembolic events.

Snake venoms induced consumption coagulopathy (VICC) is a typical common pathological feature in practically all snake families. VICC, as clinical complications begin to dominate, may increase when combined with a fatal hemorrhage as venoms contain numerous hemorrhagins (SVMPs) [75]. The hemorrhage induced by SVMPs is the consequence of cleavage of capillary basement membranes leading to an increase of the vascular permeability of blood vessels and resulting in blood extravasation (Fig. 3A) [76]. Snake venoms are capable to cause death by hemorrhage when it is intracranial [77]. In envenomed patients, VICC occurred, when several coagulation factors are activated by procoagulant compounds such as SVMPs, SVSPs and thrombin-like enzymes (TLEs), altogether, these components cause the consumption of clotting factors by snake procoagulant compounds [27, 73, 78, 79]. Multiple factor deficiencies including factors II, V, VIII, X and fibrinogen, lead to an incoagulable blood due to hypofibrinogenemia which is one of the markers of VICC [27].

Several snake venoms are mostly known to induce VICC (Table 1). Snake venom derived procoagulant-components contribute to VICC including:

- Activators of FII isolated from Echis carinatus, Pseudonaja textilis, Notechis scutatus venoms [80, 81].

- Activators of FX derived from Daboia russelii, Bothrops atrox, Cerastes cerastes, Bungarus Ophiophagus venoms $[10,82]$.

- Activators of FV identified from the venoms of Bothrops atrox and Naja naja oxiana [81]. 


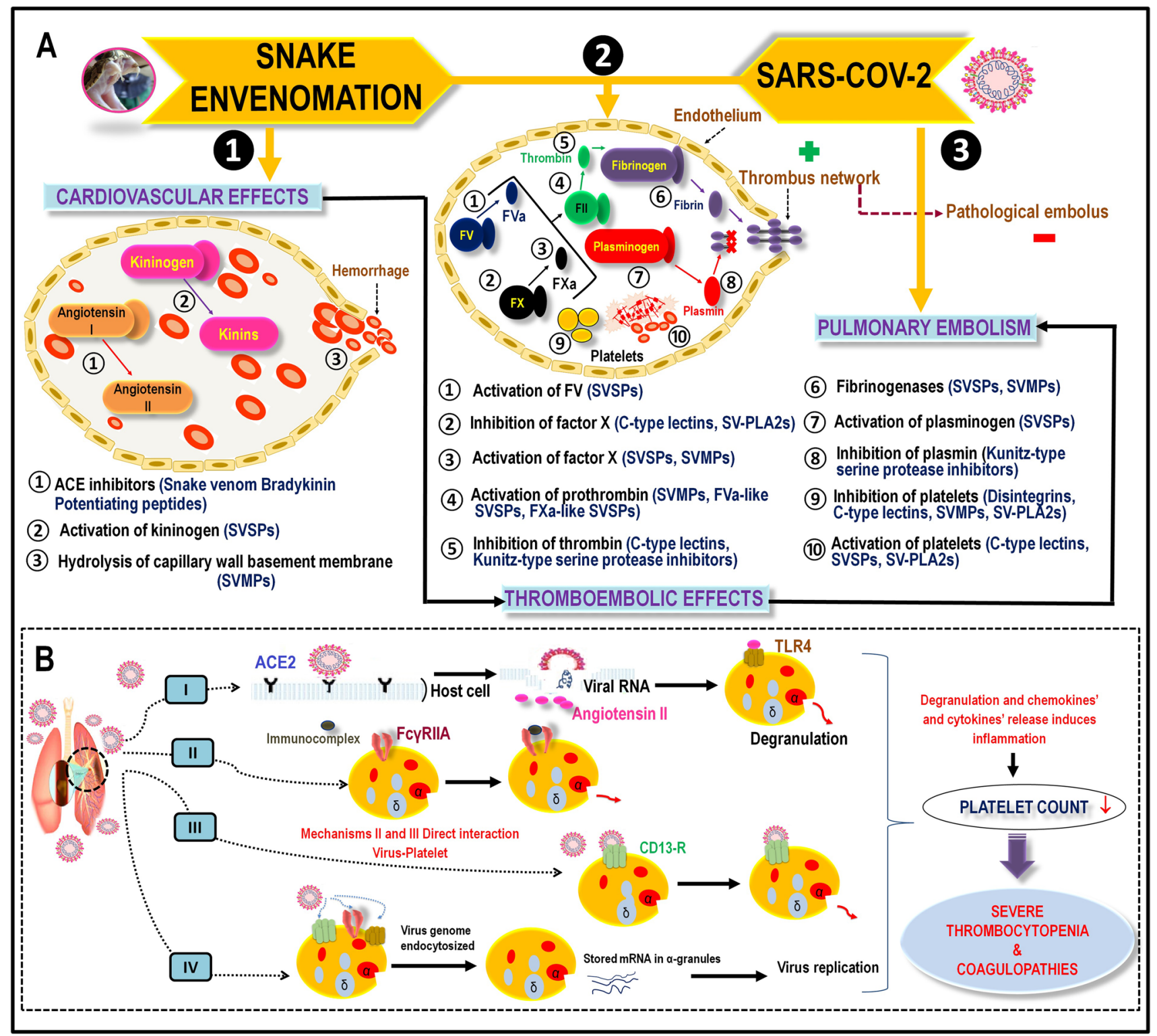

Fig. 3 Cardiovascular and thromboembolic effects induced by snake envenomation and COVID-19 pathogenesis. A Synergistic action of several snake venom compounds on cardiovascular and hemostasis systems causing together pulmonary embolism like SARS-CoV-2. B Proposed mechanism of interaction between SAR-CoV-2 and platelet receptors. Thrombocytopenia may occur via: I SARS-CoV-2/ ACE-2R interaction induces the increase in Ang II which in turn

- SVTLEs isolated from Agkistrodon contortrix contortrix venom [83].

- Activators of plasminogen purified from Trimeresurus stejnegeri venom [84]. Some investigations reported that patients experiencing VICC present high levels in some hemostatic parameters such as prolonged prothrombin time (PT), international normalized ratio (INR) and activated partial thromboplastin time (aPTT), [75, 123, 124]. interacts with TLR4 and degranulates thrombocytes. II SARS-CoV-2 may directly bind to FcyRIIA receptor. III The virus binds to CD13 of thrombocytes leading to the secretion of their granulations. IV Thrombocyte could serve as a virus production compartment; they make endocytosis of viral genomes and use their stored mRNAs for translation [75, 131-133]

These parameters (PT, aPTT and INR) are also increased in severe cases of COVID-19.

Procoagulant SVSPs seem to be alone responsible for hemotoxic effects. These procoagulant molecules displayed pharmacological effect by activating a variety of plasma blood clotting factors particularly FII, FV, FVII and FX $[30,125]$. Prothrombin activation allows thrombin release, 
Table 1 Summary of snakes known to cause venom-induced consumption coagulopathy, the procoagulant toxin, and the factor deficiencies

\begin{tabular}{|c|c|c|c|c|}
\hline Procoagulant compounds & $\begin{array}{l}\text { Snake species/ } \\
\text { Common name }\end{array}$ & Factor Deficiencies & VICC assay & References \\
\hline \multicolumn{5}{|l|}{ A/Africa } \\
\hline TLE & $\begin{array}{l}\text { Atheris squamigera } \\
\text { Green bush viper }\end{array}$ & Fibrinogen & aPTT, fibrinogen & {$[85]$} \\
\hline TLE & $\begin{array}{l}\text { Atheris chlorechis } \\
\text { Western bushviper }\end{array}$ & Fibrinogen & PT, aPTT, fibrinogen & {$[86]$} \\
\hline TLE & $\begin{array}{l}\text { Atheris nitschei } \\
\text { Great lakes bush viper }\end{array}$ & Fibrinogen & PT, aPTT, fibrinogen, D-dimer & {$[87]$} \\
\hline \multirow[t]{2}{*}{ TLE } & Cerastes cerastes & Fibrinogen, FV & $\begin{array}{l}\text { PT, aPTT, fibrinogen, D-dimer, } \\
\text { factor V }\end{array}$ & {$[88,89]$} \\
\hline & Saharan horned viper & & & \\
\hline \multirow[t]{2}{*}{ TLE (cerastobin) } & $\begin{array}{l}\text { Cerastes vipera } \\
\text { Sahara sand viper }\end{array}$ & Fibrinogen & PT, aPTT, fibrinogen, D-dimer & {$[88]$} \\
\hline & $\begin{array}{l}\text { Proatheris superciliaris } \\
\text { Lowland viper }\end{array}$ & Fibrinogen & PT, aPTT, fibrinogen, D-dimer & {$[90]$} \\
\hline \multirow[t]{2}{*}{ TLE } & Bitis arietans & Fibrinogen & $\begin{array}{l}\text { Fibrinogen, PT, clotting factor } \\
\text { studies }\end{array}$ & [91-93] \\
\hline & African puff adders & & & \\
\hline \multirow[t]{2}{*}{ TLE (Gabonase) } & Bitis gabonica & Fibrinogen & $\begin{array}{l}\text { Fibrinogen, PT, clotting factor } \\
\text { studies }\end{array}$ & [94] \\
\hline & Gaboon viper & & & \\
\hline FII activators & $\begin{array}{l}\text { Echis coloratus } \\
\text { Painted carpet viper }\end{array}$ & Fibrinogen, ?, FII, FV, FVIII & Fibrinogen, FDP, PT & {$[95,96]$} \\
\hline \multirow[t]{2}{*}{ FII activators } & Echis ocellatus & Fibrinogen, FII, FV, FVIII & $\begin{array}{l}\text { fibrinogen, clotting factor } \\
\text { studies }\end{array}$ & [97] \\
\hline & West African carpet viper & & & \\
\hline FII activators & Echis pyramidum & Fibrinogen, FII, FV, FVIII & $\begin{array}{l}\text { Fibrinogen, PT, clotting factor } \\
\text { studies }\end{array}$ & {$[98,99]$} \\
\hline SVMP* & $\begin{array}{l}\text { Northeast African carpet viper } \\
\text { Dispholidus typus } \\
\text { Boomslang }\end{array}$ & Fibrinogen & PT, aPTT, fibrinogen, FDP & {$[100]$} \\
\hline \multicolumn{5}{|l|}{ B/Asia } \\
\hline \multirow[t]{2}{*}{$\mathrm{FX}, \mathrm{FV}$ activators } & Daboia russelii & Fibrinogen, FV, FX & $\begin{array}{l}\text { WBCT20, CT, fibrinogen, clot- } \\
\text { ting factor studies }\end{array}$ & {$[101,102]$} \\
\hline & Russell's viper & & & \\
\hline $\mathrm{FX}, \mathrm{FV}$ activators & $\begin{array}{l}\text { Daboia russelii siamensis } \\
\text { Eastern Russell's viper, Siamese } \\
\text { Russell's viper }\end{array}$ & Fibrinogen, FV, FX & PT, non-clotting blood & [103] \\
\hline \multirow[t]{2}{*}{ TLE } & Hypnale hypnale & Fibrinogen, FVIII & $\begin{array}{l}\text { PT, aPTT, clotting factor stud- } \\
\text { ies, D-Dimer }\end{array}$ & [104] \\
\hline & Hump-nosed pit vipers & & & \\
\hline FII activators & $\begin{array}{l}\text { Echis carinatus } \\
\text { Saw scaled viper }\end{array}$ & NR & PT & [105] \\
\hline \multirow[t]{2}{*}{ TLE } & Calloselasma rhodostoma & Fibrinogen & $\begin{array}{l}\text { Fibrinogen, FDP, clotting factor } \\
\text { studies }\end{array}$ & [106] \\
\hline & Malayan pit viper & & & \\
\hline \multirow[t]{2}{*}{ TLE } & Trimeresurus albolabris & Fibrinogen & $\begin{array}{l}\text { Fibrinogen, FDP, fibrinopeptide } \\
\text { A, plasminogen }\end{array}$ & {$[107]$} \\
\hline & White-lipped green pit viper & & & \\
\hline TLE & Trimeresurus macrops & Fibrinogen & $\begin{array}{l}\text { Fibrinogen, FDP, fibrinopeptide } \\
\text { A, plasminogen }\end{array}$ & [108] \\
\hline
\end{tabular}


Table 1 (continued)




Table 1 (continued)

\begin{tabular}{lllll}
\hline G/Europe & & & \\
\hline FX activator & Vipera aspis & Fibrinogen & $\begin{array}{c}\text { PT, aPTT, fibrinogen, } \\
\text { D-dimer }\end{array}$ & {$[120]$} \\
\hline ND & $\begin{array}{l}\text { European asp/Asp viper } \\
\text { Vipera berus }\end{array}$ & Fibrinogen & PT, aPTT, fibrinogen, & {$[121]$} \\
& $\begin{array}{l}\text { Common European viper) } \\
\text { Vipera ammodytes ammo- } \\
\text { dytes }\end{array}$ & Fibrinogen & D-dimer \\
ND & & & PT, aPTT, fibrinogen, & {$[122]$} \\
& Dorned viper & D-dimer & \\
\hline
\end{tabular}

aPTT-activated partial thromboplastin time, CT-clotting time, VCT-venous clotting time, FDP-fibrinogen degradation products, PLA 2 -phospholipase $\mathrm{A}_{2}$, PT- prothrombin time, TLE-thrombin like enzymes, FII-factor II, FV-factor V, FX-factor X, FDP - fibrinogen degradation products; SVMP - snake venom metalloproteinase; NR - not reported

which cleaves fibrinogen, generating polymers of fibrin. The formed fibrin possibly becomes pathologic embolus if not dissolved by plasmin and may subsequently disseminate. Thrombin likewise promotes platelet aggregation which together with the fibrin clumps formation, brings about blood clotting [126]. Furthermore, proplatelet SVSPs directly bind to protease activated receptors (PAR-1/PAR4) on platelet surface and mediate fibrinogen binding to GPIIb/IIIa integrin [127]. The dual roles of SVSPs prompt the quick uptake of important coagulation factors of both extrinsic and intrinsic pathways. These multiple events may ascribe a similarity between thromboembolic abnormalities associated with COVID-19 and those subsequent from snake envenomations. Some SVSPs are good blockers of blood coagulation as either anticoagulant or thrombolytic through different mechanisms of action:

I. The anticoagulant SVSPs exhibit their effects by activating the Protein $\mathrm{C}$ that in turn inhibits FVa and FVIIIa [128].

II. SVSPs are also potent thrombolytic and are capable for eliminating blood thrombus; by acting as SVTLEs or activators of plasminogen that release plasmin cleaves the clots and induces coagulopathy [30, 129].

III. SVSPs can induce depletion of plasma coagulation factors which prevented coagulation and prompted to internal and external bleedings due to non-coagulable blood [30, 129].

Similarly to SARS-CoV-2, thrombocytes are good targets for many compounds isolated from snake venoms such as C-type lectins, disintegrins, SVSPs, and some SVMPs, Ntases and PDEs. Some proteins and peptides induce indirect platelet aggregation through binding to von Willebrand factor (vWF) or collagen and other receptors [73]. Besides, other snake venom components such as SV-PLA2s, disintegrins, C-type lectins, 3FTX are responsible for inhibiting the platelet aggregation, by blocking integrin receptors such as $\alpha_{2} \beta_{3}$ [73, 130]. VICC might be enhanced in both situations of activated or prohibited thrombocytes by snake venom compounds resulting in platelets depletion [131, 132]. Clinically, envenomed patients present severe thrombocytopenia which is a main pathogenic complication linked to COVID-19 pandemic. Thromboembolic disorders instigated by snake venoms are frequently accompanied by cardiovascular effects that resemble to infected people with SARSCoV-2 (Fig. 3A). Several compounds derived from snake venom can induce serious cardiovascular effects marked by a dramatic hypotension observed in envenomed patients.

Snake venom bradykinin potentiating peptides (BPPs) are the main component responsible for vasodilatory effects that can be additionally upgraded by certain multifunctional SVSPs [78]. Snake venoms contain various kallikrein-like SVSPs which contribute to cardiovascular effects due to their kininogenase activity releasing bradykinin from plasma kininogen [133]. At the same time, by degrading the basement membranes of capillaries, SVMPs enhanced hypotension and increased vascular permeability that leads to fall in blood pressure [76]. Snake venom hemotoxic complications including hemostasis unsettling influences and cardiovascular impacts intently take after to coagulopathy related with COVID-19 pandemic.

\subsection{Coagulopathy and Thromboembolic Disorders in Severe COVID-19}

COVID-19 presents various cardiovascular disorders accompanied with endothelial dysfunction, hypercoagulability and platelet hyperactivation leading to coagulopathy resulting in respiratory distress and pulmonary embolism [6, 134, 135] (Fig. 3 A). Patients presenting cardiovascular illness are vulnerable to risk events associated with COVID-19, while healthy people may develop cardiovascular complications after viral infection [134]. Additionally, indirect effects 


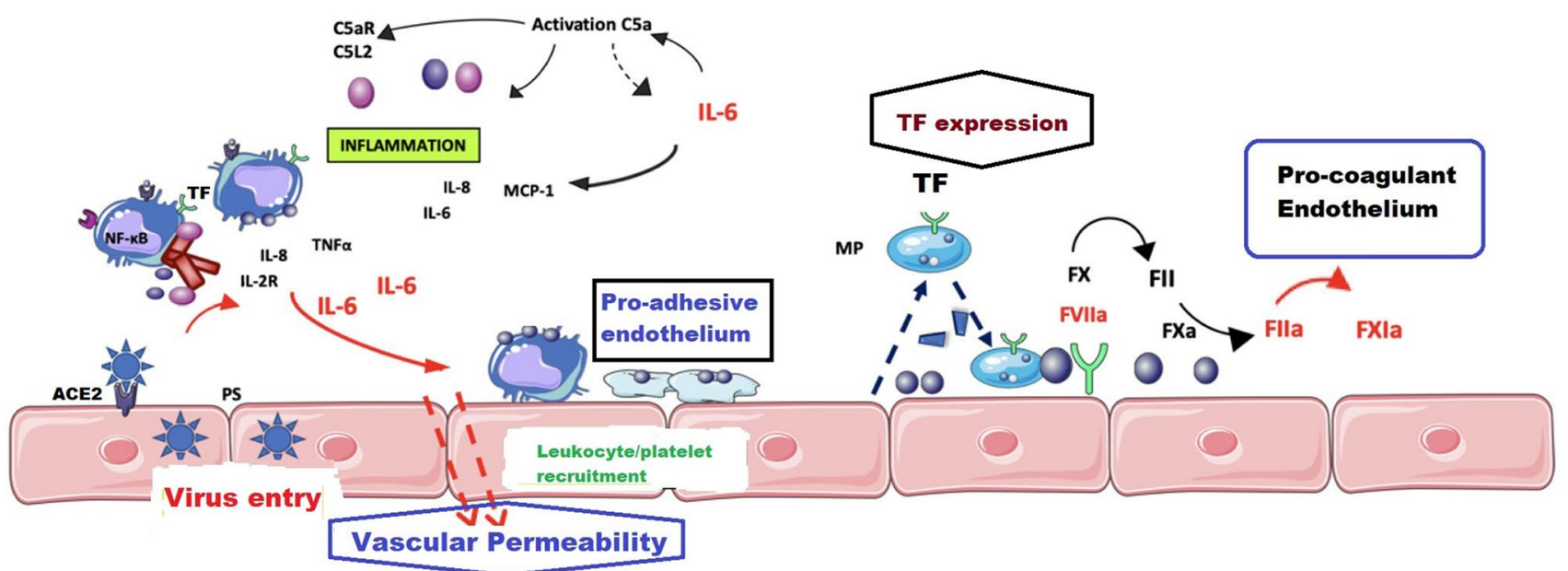

Fig. 4 Interconnection between endothelial cells, inflammatory cells, complement system and the coagulation during the thrombo-inflammatory pathogenesis of COVID-19 [144]. IL-6, partly secreted by monocytes, lymphocytes and endothelial cells in response to infection with SARS-CoV-2, increases vascular permeability, but also the secretion of other pro-inflammatory cytokines ( IL-6, IL-8 and

such as hypoxia and hyper inflammatory response increase infection with SARS-CoV-2 and predispose those infected to primarily disseminated intravascular coagulation (DIC) coagulopathy like previous outbreaks of harmful zoonotic coronaviruses [35-37, 136]. Thromboembolic disorders marked by thrombocytopenia highly emerged in COVID-19 pathogenesis particularly in severe case of patients infected by SARS-CoV-2 [137].

Coagulopathy features associated with the outcome of COVID-19 are PT, aPTT, D-dimers, fibrinogen, FDPs and antithrombin III such as in the envenomation cases [138]. Tang and collaborators [138] recommended to follow PT/ aPTT, D-dimers and platelet count in diagnosis of COVID19. COVID-19 sickness revealed a weak delayed aPTT due to the huge increase in Factor VIII and vWF [138].

SARS-CoV-2 infection can, in extreme cases, brings about in cytokine storm correlated to thrombo-inflammation called COVID-19- induced coagulopathy (CIC). CIC would be defined as an immuno-thrombotic response in critically ill patients COVID-19 that is an uncontrolled process [139]. Hemostasis abnormalities associated with COVID-19 such as in the snake envenomation are not hemorrhagic but rather prothrombotic.

Dysfunction of endothelium is considered as a major determinant of microcirculatory impairment by altering the balance of the vascular bed towards more vasoconstriction generating ischemia, inflammation and a procoagulant state. Once SARS-CoV-2 is attached to ACE2 receptor, alteration of endothelial cells (ECs) leads to the release of tissue factor which binds FVII and initiates extrinsic coagulation pathway [140]. Multiple organ failure (MOF) revealed endothelial
MCP-1) by endothelial cells contributing to the cytokine storm. The endothelium thus becomes pro-adhesive. Finally, endotheliitis also participates in the hyper-expression of tissue factor (TF), a major activator of coagulation. ( $I L$ interleukin, $C$ complement, $F$ coagulation factor, $M P$ microparticles, $P S$ phosphatidylserine, $M C P-1$ monocyte chemo-attractant protein 1 also called CCL2)

inflammation in all affected organs (lung, kidneys, intestinal mucosa and heart) and in altered ECs suggesting a direct involvement of the virus in the disease onset of endothelial dysfunction [141]. This endothelial dysfunction could generate a systemic procoagulant state in addition to specific organ damage.

ECs likewise contributed to regulate blood flow due to their ability to inhibit thrombogenicity; therefore, blood components pass easily through the vascular system [142]. In pathophysiological situation such as an induced hyperinflammation with SARS-CoV-2 infection, ECs switch to generate an anti-fibrinolytic and prothrombotic microenvironment and mainly participate in thromboembolism [142]. These events are assimilated to those observed in the current pandemic where the renin angiotensin aldosterone system (RAAS) is intrinsically associated with the coagulation pathways and may drive microthrombi development in COVID19 positive individuals by enhancing of the immuno-thrombosis process [143].

Different mechanistic explanations in relation to EC can be put forward regarding the relationship between hypercoagulability and the immuno-pathogenesis of COVID-19 (Fig. 4):

- Ang II induces the release of TF and plasminogen activator-1 inhibitor (PAI-1) by ECs via the AT-1R receptor (angiotensin-type -1 receptor), this contributes to an imbalance the PAI-1/tPA ratio marked by a high coagulability and deposits of unresolved thrombus in alveoli of patients suffering from ARDS and pulmonary thromboembolism in COVID-19 individuals [145]. 
- The up regulation of released TF from ECs leads to the formation of TF-FVIIa complex and activation of the extravascular blood clotting pathway. This activation generates a direct release of thrombin from FII and leads to thrombus deposits in numerous tissues particularly the lungs [146].

- The elevated amounts of both factors vWF and FVIII linked to a significant endothelial inflammation [147].

- Various pro-inflammatory cytokines (IL-1, IL-6, and TNF- $\alpha$ ) are activated due to the injury of ECs [148]. These pro-inflammatory mediators contribute to microvasculature plugging and thromboembolism in lungs.

- ACE metabolizes bradykinin which stimulates vasodilatation and release of tPA from ECs as do BBPs from snake venoms [78, 133, 143].

Several other studies reported the involvement of elevated Ang II as a major mediator in coagulopathy associated with COVID-19. According to Stoll and collaborators [149], Ang II stimulated the increase in aldosterone which further improved the activity of ACE and attenuated the increase in tPA mediated by bradykinin. Hyper-aldosterone appears to correlate with the levels of PAI-1 and directly increases the expression of PAI-1 [150]. Although bradykinin may be elevated, the increase in ACE, Ang II and aldosterone will likely be more marked, with reduction in the tPA to PAI-1 ratio leading to fibrinolysis prevention [151]. Besides the generation of microthrombi as a general feature of COVID19 patients, the imbalanced ratio of tPA versus. PAI-1 may be correlated to significant pulmonary thrombosis [145].

\section{Cytokine Storm and Complement System: Interaction Between Inflammation and Coagulopathy in COVID-19}

Several studies revealed the close relationship between thrombosis disorders and inflammatory response in COVID19 , which called thrombo-inflammatory response. There is a direct link between the innate immune system and hemostasis related to a hyperinflammatory profile that promotes endothelial dysfunction and induces a prothrombotic state. During disease, clots are formed through a thrombo-inflammation process involving thrombocytes, factors of coagulation and some effectors of innate immune system (macrophages, polynuclear neutrophils and the complement), $[152,153]$.

Many associated patholological events occurred simultaneously when ACE2 is inhibited due to SARS-CoV2/ ACE-2 receptor attachment leading to an uncontrolled and widespread immunothrombosis and microangiopathy. These events contribute to progression to COVID-19-induced ARDS [153]. In infected patients with SARS-CoV2, many events such as vasoconstriction [154], proinflammatory cytokine profile and C-reactive protein [155] [156], pulmonary fibrosis [145] and DIC [139] participated together to induce ARDS evolution [157].

Both IL- 6 and TNF $\alpha$ are involved in DIC that causes coagulopathy in sepsis due to inappropriate mechanisms of anticoagulation (antithrombin, tissue factor pathway inhibitor (TFPI) and the protein C system) and inactivated fibrinolysis with the high levels of PAI-1 [158]. In COVID-19, a cytokine storm characterized by deadly hyper-cytokinemia leads, in most cases, to multi-organ dysfunctional syndrome [159].

With regards to vascular complication associated with COVID-19, coagulopathy seems to be driven by pro-inflammatory cytokines [160] known as cytokine storm that is characterized by deadly hyper-cytokinemia and leads, in most cases, to multi-organ dysfunctional syndrome [143]. Pro-inflammatory cytokines may also induce the release of $\mathrm{vWF}$, production of TF and FVII/FVIIa leading to increased thrombin generation, and decreased levels of endogenous anticoagulants [160]. Otherwise, the increased procoagulants combined to decreased anticoagulants, preventing resulted thrombolysis in the broad interchange between ECs, platelets, complement system, macrophages, polynuclear neutrophils and hemostasis process. The initiation of extravascular blood clotting pathway by TF released by ECs results from inflammation [153]. Intravascular blood clotting pathway initiated by FXII, and KKS is also triggered. All these events evidenced that thromboembolic disorders and particularly pulmonary embolism are driven by hyperinflammation through cytokine storm.

The IL-6 is associated with severity in COVID-19 pathogenesis; it appears to be involved in the high expression of the serum ferritin which is also a biomarker of the severity of COVID-19 [43]. In addition to IL-6, various increased inflammatory mediators of Th-1 pathway such as IL- $1 \beta$, IL-12, IL-18, IL-33, CCL2, CXCL10 and TNF- $\alpha$ are found in severely infected individuals [43].

Two signalling pathways may explain the role of IL-6 during cytokine storm in COVID-19:

- Cis signaling in which the attachment of IL-6 to its receptor and gp130 downstreams the Janus kinases' signal transducer [161].

- Trans signaling, the binding of IL-6/soluble IL-6 leads to the release of IL-8 and vascular endothelial growth factor (VEGF) whereas it downregulates the expression of E-cadherin ECs [161].

Several studies reported the pivotal role of the complement system as potentiating event of thrombo-inflammation associated with SARS-CoV-2 infection [162, 163]. In the innate immune system, components from the system of 
complement circulate in inactive form until they are needed. In COVID-19 pathogenesis, the complement system is responsible for triggering inflammo-thrombosis due to its role of opsonising pathogens. The crosstalk between the complement and coagulation systems was reported in many studies which revealed that the thrombotic complications in COVID-19 are related, in part, to complement activation [163]. The complement system can be activated at least by one of three pathways (classical, alternative and lectin pathways). The complement system induces a cascade of events generating some components (C3a, C5a and, MA; membrane attack complex) [164].

Once activated during thrombo-inflammation associated with COVID-19, the components of complement system such as C3a, C5a MASP-1 and MASP-2 contribute to the:

- Dysregulation of neutrophilia, endothelial dysfunction, and hypercoagulability.

- Degranulation and recruitment of macrophages and mast cells [164].

- Platelets activation and ECs, increasing TF and vWF expression [164].

- Generation of thrombin and fibrin from prothrombin to and fibrinogen respectively [165].

On the other hand, the close relationship between coagulation and complement pathways might be additionally upgraded by some activated factors of coagulation which can directly interact with components of complement (C3 and C5) [165].

\section{Role of Platelets in Cytokine Storm and Mechanisms of Thrombosis in Severe COVID- 19}

Thrombocytopenia appears to be a determinant predictive element for the COVID-19 severity while lymphopenia is believed to be a result of a failing immune response to SARS-CoV-2 [166]. At the same time, thrombocytes, wellknown cells in hemostasis also significantly evolved proinflammatory role which enhances the resulting thromboinflammation in COVID-19 illness through direct or indirect hyperactivation of platelets following viral infection [167]. Both ventilation and SARS-CoV-2 infection disrupt lungendothelium resulting in platelet hyperactivation since about the half of total platelets is produced in lungs, this makes pulmonary parenchyma vulnerable to directly high infectivity and inflammation. Ultimately, due to this hyperinflammation, a thickness in alveolar walls contributes to severe hypoxia [168].

Furthermore, during hemostasis process, the thrombocytes initiated the coagulation cascade that can be also stimulated by thrombin through PAR-1 and PAR-4 receptors. A surface of phospholipids (PLs) from thrombocytes once stimulated is required for the activation of several factors of coagulation at many stages of coagulation pathways [169].

Direct binding of coronavirus on platelets was previously reported with HCoV-229E antigens [170]. Based on the high similarity $(\sim 82 \%)$ between these both $\beta$-coronaviruses, Bhotla and collaborators proposed mechanisms of binding of SARS-CoV-2 on platelets that may elucidate the pulmonary embolism [171]. HCoV-229E interacts with the epithelial cells of lungs through the aminopeptidase N (CD13) as overexpressed receptors during viral infection [170]. Platelets also express CD13 of HCoV-229E as well as bone marrow cells; therefore, the virus entry is mediated through CD13 receptors. Once infected, bone marrow cells are dysregulated and lead to defective hematopoiesis resulting in thrombocytopenia [170].

Four mechanisms for thrombocytopenia associated with pulmonary embolism can be proposed [171], and outlined in Fig. 3B:

I. SARS-CoV-2/ACE-2R interaction induces the increase in Ang II which in turn interacts with TLR4 and degranulates thrombocytes.

II. SARS-CoV-2 may directly bind to Fc $\gamma$ RIIA receptor.

III. The virus binds to CD13 of thrombocytes leading to the secretion of their granulations.

IV. Thrombocyte could serve as a virus production compartment; they make endocytosis of viral genomes and use their stored mRNAs for translation.

Through analogy, hypothetical mechanisms of thrombocytopenia associated with COVID-19 pathogenesis were reported [166]:

- Inhibition of platelet synthesis due to a direct infection of bone marrow cells.

- Destruction of platelet by the immune system.

- Aggregation of platelets in the lungs leading to increase of their consumption.

Among the various Toll-like receptors (TLR) expressed by platelets, the TLR- 4 was reported to be the target receptor for Ang II and contributed to the pro-inflammation, functional impairment of pulmonary platelets and triggering their degranulation [172]. Other reported mechanisms relative to thrombocytopenia focused on the antiplatelet autoantibodies that might be stimulated following inflectional process and can trigger destruction of platelets. Xu and collaborators put the hypothesis that the platelets predisposed to easy destruction by the reticulo-endothelial system due to deposition of immune complexes on platelet surfaces [166]. 


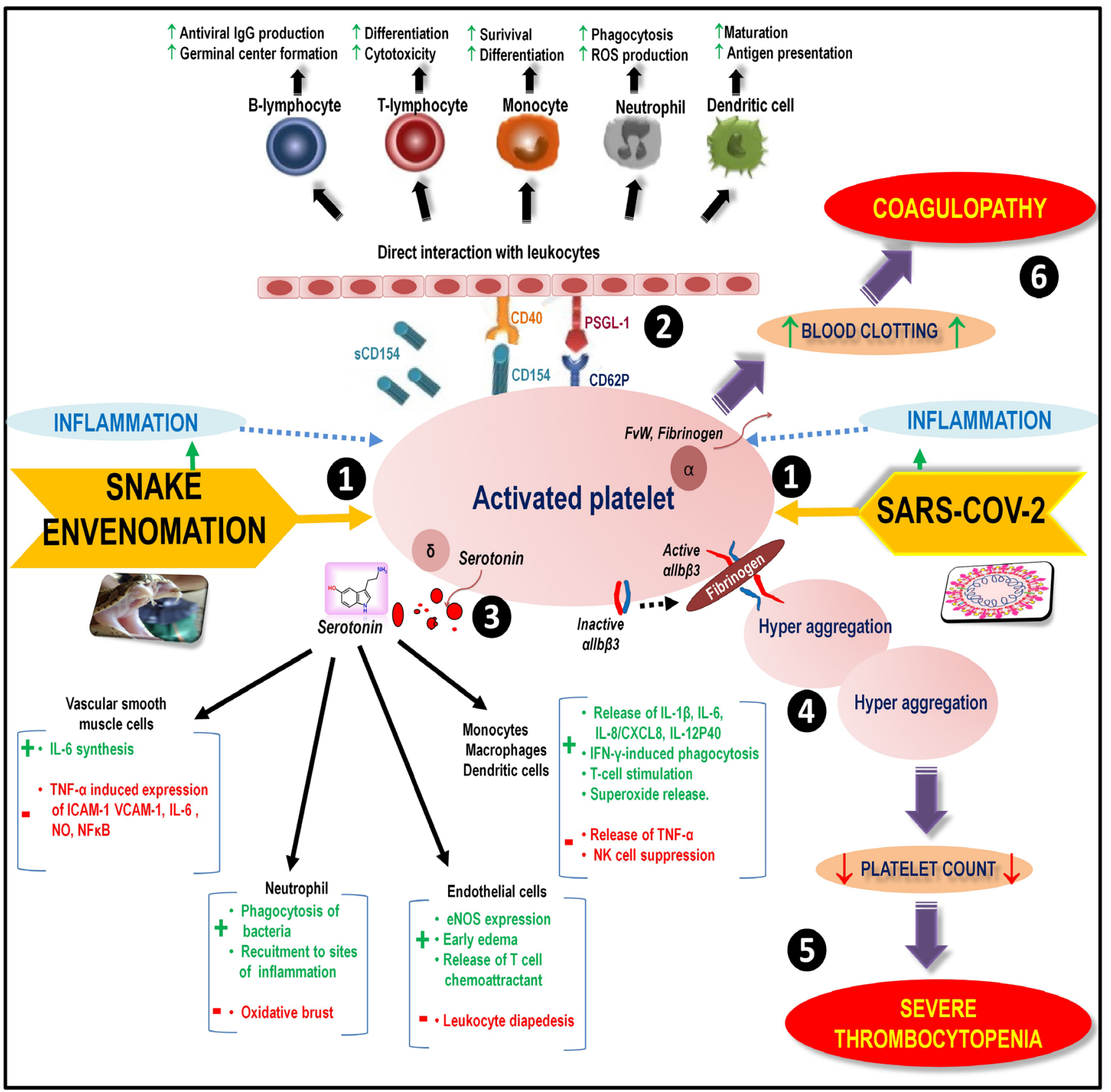

Fig. 5 Potential involvement of snake venoms and SARS-CoV-2 in hyperactivation of platelets and resulting thrombo-inflammatory complications. (1) Direct action of targeted platelets by snake venom and SARS-CoV-2 inducing change in shape of circulating platelets, their spread and secretion of dense and $\alpha$ granulations. (2) Direct interaction of activated platelets with leukocytes through expressed CD62P (P-selectin receptor) that binds to PSGL-1 and various leukocyte receptors, TLR4 promoted platelet and neutrophil interactions lead-

When activated, the platelet changes it shape and releases the stored components in its granules such as P-selectin, serotonin, cytokines and chemokines (Fig. 5). Because of their potential to release high amounts of pro-inflammatory IL-1 $\beta$, the platelets are considered as a good source of this cytokine ing to neutrophil extracellular traps 3 Platelet degranulation and release of serotonin that exhibits diverse proinflammatory effects. 4 and 5Hyperactivation of platelets and thrombocytopenia induced by snake envenomation and COVID-19.6 Degranulation of $\alpha$-granules of hyperactiveted platelets associated with snake envenomation and COVID-19 resulting in FvW and Fibrinogen release and coagulopathy $[172,173]$

underling their role in the immune thrombotic process. Furthermore, $\alpha$-granules contain a variety of immunostimulatory components that are activate and recruit macrophages and PMNs such as proplatelet basic protein, platelet factor 4 (CXCL4) and neutrophil-activating peptide-2 (CXCL7). 




Fig. 6 Different platelet receptors and therapy. (A) Platelet receptors for several viruses including SARS-CoV-2 and ACE2. (B) Antiplatelet therapy, the receptors of platelets are the targets of venom proteins

The recruited PMNs can undergo NETosis when stimulated by P-selectin that facilitates platelet-neutrophil complexes' formation [173]. that inhibit platelet aggregation as well as conventional antiplatelet drugs [23, 177-179]

It was reported that platelets expressed ACE2 and TMPRSS2 (Fig. 6A) [174]. Spike protein of SARS-CoV-2 is responsible for enhancing platelet activation at different stages (CD62P expression, $\alpha$ - and dense granules' release 
and secretion and spreading of platelets), and thereby Spike protein enhanced thrombosis formation by facilitating the release of coagulation factors. These data may explain further the crucial involvement of hyperactivation of platelets in cytokine storm leading to thrombocytopenia and lung thromboembolism associated with COVID-19 pathogenesis.

COVID-19 is associated with coagulative disorders as patients have increased platelet activation and aggregation, and platelet-monocyte aggregation [175]. These coagulation disorders highlight the critical role of platelets in SARSCoV-2 infection and immunopathology. Both platelets and megakaryocytes directly interact with SARS-CoV-2, raising the concern whether ACE2 receptor plays a role in this interaction. Abundance of ACE2 receptor and alternative receptors or co-factors for SARS-CoV-2 entry was characterized in platelets from COVID-19 patients and healthy persons as well as human megakaryocytes based on laboratory tests or previously reported RNA-sequence data. The results suggest that SARS-CoV-2 interacts with platelets and megakaryocytes via ACE2-independent mechanism and may regulate alternative receptor expression associated with COVID-19 coagulation dysfunction [176].

\section{Therapeutics and Diagnostics Derived from Snake Venom Against a Wide Range of Diseases}

Snake venoms are a mixture of bioactive compounds that were previously studied for their involved role in pathophysiological envenomation, while in recent years; they are explored for their potential use as new drugs as biotherapeutics for many public health concerns $[9,180]$. Snake venom components are attracting the attention of pharmaceutical industry for their potential therapeutic values. Several snake venoms derived-drugs are either in clinical trials or in use (Table 2). Cobra venom was used already to treat inflammation, arthritis, joint pain, opium addiction or combined with opium to treat pain.

Snake venoms are a valuable bank of novel generation of principle components in drug discovery, nevertheless, only a limited number of components has been identified, from which some FDA-approved drugs are now used as medicine [28]. Some proteins and peptides derived from snake venoms are in preclinical phase or clinical trials to be used for some pathologies (Table 2).

\subsection{Approved Drugs Derived from Snake Venom Peptides and Proteins as Possible Potential Anti-SARS-COV-2 Drugs}

Snake venoms become a novel natural pharmacopeia to develop new drugs, since the approval of Captopril, the first antihypertensive snake venom-derived drug:

- Captopril@ (FDA approval in 1981): The drug is a biomimetic of BBPs isolated from Bothrops jararaca venom (Brazil). It is used to treat high blood pressure with regard to its inhibitory potential on ACE [181]. Many derivatives of Captopril ${ }^{\circledR}$ have been successfully produced by Squibb and other companies and are being introduced into the market [182-184] (Table 2A). Snake venom BBPs could be effective drugs by decreasing the over expression of ACE-2. Captopril as an ACE inhibitor blocks the production of Ang II (a potent vasoconstrictor), and therefore leads to a decrease in arterial resistance. ACE (a zinc metalloprotease) releases Ang II from Ang I (inactive peptide) after peptide bond hydrolysis. The zinc atom of the active site plays a catalytic role by activating the water molecule. Captopril works by blocking the vacant coordination of zinc with its thiol function. Many BBPs such as BBP-10c have been isolated from snake venom [185]. BPP-10c strongly reduced Ang II by inhibiting ACE and increasing bradykinin-related effects on the bradykinin 2-receptor [185] (Table 2A).

- Aggrastat ${ }^{\circledR}$ (Tirofiban, FDA approval in 1998): Aggrastat ${ }^{\circledR}$ is extracted from Echis carinatus venom and belongs to disintegrins, it is an antiplatelet drug containing the RGD sequence (Arg-Gly-Asp) motif [186, 187]. Disintegrins are group of small peptides cysteine-rich and originally purified from the venoms of Viperidae snakes [188]. Tirofiban was originally developed by Merck but now it is marketed by Medicure Pharma in the US and Correvio International outside of the US (Table 2A).

- Integrilin ${ }^{\circledR}$ (Eptifibatide, FDA approval in 1998): Integrilin ${ }^{\circledR}$ (Eptifibatide, FDA approval in 1998): It isolated from the venom of Southeastern rattlesnake by Millennium Pharmaceuticals [186], this KGD (Lys-Gly-Asp)disintegrin mediated platelet aggregation and, therefore, it treated individuals suffering from cardiovascular complications (unstable angina and myocardial infarctions and acute coronay syndrome) and prevented deadly heart attack in vulnerable patients [17, 189]. Eptifibatide is a GPII/bIIIa inhibitor obtained from Sistrurus barbouri venom, designed as peptide mimicking a small portion of barbourin, [190] (Table 2A). Several snake venom containing RGD-disintegrins are isolated and well characterized as effectively anticoagulant therapeutics and platelet inhibitors by targeting selectively GPIIb/IIIa 










integrin [202]. Antiplatelet therapy is needed to combat thrombocytopenia and severely complicated thromboembolic disturbances associated with COVID-19 pandemic. Disintegrins derived from snake venoms are potential candidates as antithrombotic therapeutics [202].

- Defibrase ${ }^{\circledR / R e p t i l a s e}{ }^{\circledR}$ (Batroxobin, approved clinically in the US, but approved for use in other countries): Defibrase ${ }^{\circledR}$ also referred as to Reptilase ${ }^{\circledR}$ (Batroxobin, approved clinically in some countries including USA): This drug is a SVSP derived from two bothroptic venoms (Bothrops atrox and Bothrops moojeni) [192]. Batroxobin, as several SVTLEs is $\alpha$ fibrinogenase releasing only fibrinopeptide A upon cleavage of the $\alpha$-chain of fibrinogen whereas its $\beta$-chain remains uncleaved [184]. Such SVTLEs are not sensitive to physiological serine protease inhibitors $[19,184]$. Cerebral and myocardial infarction, ischemic stroke and angina are the main diseases that are currently treated by Defibrase ${ }^{\circledR}$ [78]. Batroxobin drug is now commercialized with different names:

- Batroxobin and Reptilase (Tobishi Pharmaceutical, China) [203].

- Defibrase (DSM Nutritional Products Ltd Branch Pentapharm, Switzerland) and Botropase (Hanlim, South Korea)[203].

- Botroclot (Juggat Pharma, India) [203].

- Plateltex-Act ${ }^{\circledR}$ (Czech Republic) [204] and Vivostat System (Denmark)[205]. Both of them are valuable biotherapeutics and currently served as tools as autologous platelet-gels in cellular therapy [206, 207].

Batroxobin, is widely utilized for perioperative bleeding and as effective and safe bio-drug for array illnesses including pulmonary embolism and deep vein thrombosis [28]. This opens prospect to introduce Batroxobin in therapeutic strategy anti- COVID-19 aiming to prevent the fatal pulmonary embolism often associated with severe individual infected by SARSCoV-2.

- Viprinex ${ }^{\circledR}$ (Arvin/DrugBank Accession Number DB05099): a SVSP commonly known as Ancrod that previously identified in Calloselasma rhodostoma venom. Pharmacologically, Viprinex® displays defibrinating effect resulting from the proteolysis of fibrinogen. Thusly, the therapeutic indications of this anticoagulant drug include ischemia, deep-vein thrombosis, myocardial infarction and individuals present with thrombocytopenia [208, 209]. The anticoagulant effects of Ancrod are due to the rapid removal of fibrinogen from the blood within hours following drug administration. Ancrod specifically cleaves only the $\alpha$-chain of fibrinogen, pro- ducing only the fibrinopeptides A. The resulting fibrin polymers are imperfectly formed and much smaller in size $(1$ to $2 \mu \mathrm{m})$ than that produced by thrombin. These ancrod-induced microthrombi do not cross-link to form thrombi as they are friable, unstable, urea-soluble and significantly degraded $\alpha$-chains. These microthrombi are markedly hydrolyzed by plasmin and are rapidly removed from circulation by either reticulo-endothelial phagocytosis or normal fibrinolysis, or both. Blood viscosity is reduced by $30-40 \%$.

Furthermore, Ancrod does not activate Factor XIII and plasminogen; it does not degrade the preformed and fully cross-linked fibrin as thrombin. Consequently, unlike fibrinolytic agents, Ancrod can be used post-operatively. This venom-derived drug induces platelet aggregation, the release of ADP, ATP, potassium and serotonin from platelets [209].

\subsection{Diagnostic Tool Derived from Snake Venom Peptides and Proteins for Testing Coagulopathy Associated with COVID-19}

Snake venom peptides and proteins are not only used therapeutics but a number of them are valued as successful biodiagnostics for three decades (Table 2B).

- Textilinin-1 (commercialized under the moniker Q8008): derived from Pseudonaja textilis venom, is a specific inhibitor peptide of plasmin. It presents properties as an anti-thrombolytic potential. This peptide is applied to reduce blood loss resulting in complex surgeries [193] (Table 2B).

- Hempatch: identified in the venom of Pseudonaja textilis, it combines both FXa- and FVa-like factors with its dual potentials, it is a used in translational medicine (Table 2B). Hempatch (control bleeding tool) and CoVase (anti-hemorrhagic agent) are given names to FXa-like and FVa-like proteins respectively [184, 193].

- Reptilase ${ }^{\circledR}$ : the unique approved drug from snake venoms used as dual agents (therapeutics and diagnostics). Reptilase ${ }^{\circledR}$ is applied as a laboratory reagent instead of thrombin to quantify fibrinogenemia and to diagnose coagulation disorders (Reptilase ${ }^{\circledR}$ time), [194]. Reptilase ${ }^{\circledR}$ test presents an interest as it does not require cofactors (phospholipids and Calcium), leading to prohibit platelet aggregation and inactivate platelet dependentcoagulation factors [195].


venom of Daboia russelii is a rich source of SVSPs from which Pefakit ${ }^{\circledR}$ has been characterized as a FVa-like protease $(27 \mathrm{kDa})$ [196]. To date, laboratories perform Pefakit ${ }^{\circledR}$ test to diagnose patients present with resistance 
to activated protein $\mathrm{C}$ and lupus anticoagulant characterized by the presence of antiphospholipid antibodies [195-197] (Table 2B).

- Stypven ${ }^{\circledR}$ : RVV-X is a macromolecule with $120 \mathrm{kDa}$ isolated from Daboia russelii venom and capable for inducing a direct FX activation [82, 198]. This protein requires cofactors $(\mathrm{Ca} 2+, \mathrm{FV}$, phospholipids and FII) to be activate [195]. Stypven ${ }^{\circledR}$ is also used as Pefakit ${ }^{\circledR}$, to diagnose patients suffering from the manifestations of antiphospholipid syndrome [195].

- Ecarin: A metalloprotease prothrombin activator purified from the venom of Echis carinatus. Ecarin is a very useful reagent since it acts without any cofactors for thrombin clotting assay [195]. Ecarin test is used to detect different abnormal types of FII [199]. Ecarin, such as Stypve ${ }^{\mathrm{n}} \circledast$ and Pefaki ${ }^{\mathrm{t}} \circledast$, is the third snake venom derived-diagnostics drug that is used for lupus anticoagulant diagnosis (Table 2B).

- Botrocetin ${ }^{\circledR}$ : Also termed "Venom coagglutinin", is a C- type lectin-like protein $(22 \mathrm{kDa})$ purified from the venom Bothrops jararaca. Botrocetin ${ }^{\circledR}$ mediates the platelet aggregation by binding to GPIb $\alpha$ and enhancing the affinity to its ligand vWF [200].

- ACC-C (Protac $®)$ : obtained from Agkistrodon contortrix venom [210]. It is an activator of protein C. which interact with protein $\mathrm{S}$ and $\mathrm{C}$ to quantify their plasma levels. Protac ${ }^{\circledR}$. Protac ${ }^{\circledR}$ assay presents a significance since AAC-C activity is not affected by protein C plasma inhibitors [195]. Protac $®$ depends on the prolongation of aPTT to investigate the cause of thromboembolism associated with deep vein thrombosis [210]

- MT $\alpha$ and KT-6.93 are small peptides members of ThreeFinger Toxins' family. Both compounds have been utilized in biodiagnostics of blood pressure and disorders associated with blood coagulopathy [201] (Table 2B).

\section{Anti-SARS-CoV-2 Therapeutic Possibilities from Snake Venom Compounds}

There are various on-going active clinical trials to potentially treat SARS-CoV-2 under investigations across the world. No clinical trials have confirmed significant efficacy against SARS-CoV-2 including anti-malarial and anti-retroviral agents [163].

Further, clinical trials on the plasma of patients and the antibodies anti-SARS-CoV-2 were not effective. These failed trails of treatments against COVID-19 gave rise to the need to investigate for natural compounds. Snake venoms could present a potentially valuable resource of pharmacological agents in the management of this pandemic disease.

\subsection{Defibrinating, Anticoagulant and Thrombolytic Snake Venom Compounds}

\subsubsection{Defibrinating and Thrombolytic Thrombin-Like Enzymes}

SVTLEs are assimilated to thrombin due to their ability to clot plasma by cleaving fibrinogen [8]. Whereas, unlike thrombin, these serine proteases are not able to activate FXIII required for stabilizing formed thrombus. In this case, the produced clots by SVTLEs are unstable and easily cleared [127, 211]. These characteristics make SVTLEs good candidates as lead bio-compound therapeutics or diagnostics to dissolve undesirable embolus resulting in platelet hyperactivation and coagulation associated with COVID-19 pathogenesis.

Our group has previously reported a variety of SVTLEs identified and purified from snake venoms, their interesting pharmacological potentials were also characterized (Table 3). SVTLEs are classified into three families, according to the released fibrinopeptide (FP), (i) $\alpha$ - fibrinogenases releasing the FPA of the A $\alpha$ chain of fibrinogen, (ii) $\beta$-fibrinogenases releasing the FPB of the $\mathrm{B} \beta$ chain of fibrinogen and (iii) $\alpha, \beta$-fibrinogenases cleaving both fibrinogen chains. However, they usually release either FPA or FPB similar to thrombin $[30,128]$. They inhibit and/or activate platelet aggregation and/or blood coagulation and exhibit a potential pharmacological antithrombotic effect.

Moreover, pro-platelet SVSPs act directly on platelet receptors promoting the formation of bridge between platelets which is the result of fibrinogen binding to GPIIb/IIIa integrin [127]. These anticoagulant SVTLEs may activate also Protein $\mathrm{C}$, which in turn prevents the activation of $\mathrm{FVa}$ and FVIIIa [128]. Thrombolytic SVTLEs are also able to activate the plasminogen activators (t-PA) to eliminate the produced thrombus, this leads to attenuate coagulopathy [ 30 , 129].

Despite their fibrinogenase activity, SVTLEs are anticoagulant agents that can be used as therapeutic agents to treat thrombosis associated with COVID-19 pandemic. The cleavage of fibrinogen by SVTLEs leads to defibrination which can be enhanced as they exhibit plasmin-like activity [184].

Several studies on SVTLEs have reported their thrombolytic role suggesting a direct action on vascular endothelial cells promoting the release. This effect may potentially be interesting in their possible use as anticoagulants for COVID-19 pandemic (Fig. 7, Table 3).

\subsubsection{Snake Venom Kunitz-type inhibitors as potential blockers of SARS-CoV-2 Entry}

Kunitz-type peptides are the smallest components found in the snake venoms, their length comprise of about 50 to 
60 amino acid residues. Kunitz-type peptides can interact with an array of serine proteases and inhibit their catalytic site, they are also called bovine pancreatic trypsin inhibitors (BPTIs) [212]. These characteristics make snake venom BPTIs as potential antiviral agents when target TMPRSS2 activity required for SARS-CoV-2 entry.

Treatment of patients with the snake venom BPTIs could block the entry of SARS-CoV-2 and prevent inflectional process. Several BPTIs have been found in snake venoms (Fig. 7, Table 3B). In envenomed victims, BPTIs impaired hemostatic system and block potassium channels [213], or both [214]. Thus, snake venom BPTIs may have dual interests as anti-SARS-CoV-2 as anticoagulant and inhibitors of TMPRSS2.

\subsubsection{Anticoagulant PLA2s}

Some snake venom PLA2 (SV-PLA2) inhibit blood coagulation $[215,216]$. They are classified into coagulant (strong or weak) or anticoagulant. Many coagulation factors need phospholipids for their activation and interaction between each other. Thus, SV-PLA2 exhibit anticoagulant effects through an enzymatic mechanism by hydrolyzing phospholipid surfaces, subsequently, the prevent platelet activation and inactivation of coagulation cascade [128]. Additionally, strong anticoagulant PLA2 are able to inhibit coagulation through non-enzymatic mechanism since they are capable to selectively target and bind to FXa with high affinity, thereby, SV-PLA2 inhibit prothrombinase complex and prevent thrombin generation [217].

Another mechanism of anticoagulation underlined by almost all SV-PLA2 inhibit the extrinsic tenase complex (TF-FVIIa), [218]. Both enzymatic and non-enzymatic mechanisms that allow to inhibiting the tenase complex give a rise evidence on the strong role of SV-PLA2 as strong anticoagulant. This promising anticoagulant potential leads to an application of SV-PLA2 as anticoagulant agents in COVID-19 therapy (Fig. 7, Table 3A).

\subsection{Antiplatelet Snake Venom Compounds}

\subsubsection{Disintegrins, C-Type Lectins and Three-Finger Toxins (FTX)}

Snake venoms contain also non-enzymatic components represented by C-type lectin-related proteins that were the first peptides to be identified as potent anticoagulant and antiplatelet compounds [219, 220]. C-type lectin-related proteins interact directly with some factors of coagulations such as FIXa, FXa and thrombin or through binding on platelet receptors [221, 222]. Structural modeling and mechanism of action of C-type lectins have revealed their potential antiplatelet activity such as Cc-Lec [24] (Fig. 6B,
Fig. 7, Table 3B). The formation of the platelet-platelet bridge is mediated by the binding of fibrinogen to its GPIIb/ IIIa receptor also referred to as $\alpha \operatorname{IIb} \beta 3$ integrin [202]. It has been considered as a pharmacological target in the therapy of thrombosis diseases, due to the role of this receptor in the platelet aggregation.

Many GPIIb/IIIa inhibitors such as Tirofiban and Eptifibatide are developed from snake venoms and commercialized for patients with acute coronary syndrome or undergoing percutaneous coronary interventions [186]. Further, several $\alpha_{\mathrm{IIb}} \beta_{3}$ integrin blockers from snake venoms were reported (Fig. 6B, Fig. 7, Table 3B).

The anticoagulant and antiplatelet effects of three-finger toxins were the first identified cardiotoxin isolated from Naja nigricollis venom [223, 224]. The mechanism of antiplatelet action of these cardiotoxins has been well elucidated [225]. Several 3-FTX anticoagulant and antiplatelet effects have been characterized (Table 3B).

\subsubsection{Nucleotidases, Phosphodiesterases and Nucleases}

Nucleotidases and phosphodiesterases of snake venoms are phosphate-releasing enzymes that exhibit dual anti-platelet and anti-thrombotic activity. However, they do not directly interact with platelets but rather cleave ADP to AMP and phosphate. The released phosphate, in turn, binds to A2 platelet receptor and inhibits aggregation. Several members of enzymes have been characterized from snake venom as antiplatelet agents [23, 228] (Table 3B).

Snake venom derived-compounds may be used for treatment of coagulopathy associated with COVID-19 as an alternative to the other conventional anticoagulant drugs. They are natural molecules with less side-effects which make them superior to synthetic drugs. As mentioned in Table 3A, $3 \mathrm{~B}$ and $3 \mathrm{C}$, the drug-induced immune thrombocytopenia and severe reactions are the most severe side effects of Tirofiban and Eptifibatide as $\alpha \operatorname{IIb} \beta 3$ antagonists [244]. The thrombocytopenia was restored by Tirofiban and Eptifibatide two weeks post-treatment. However, this thrombocytopenia persists when thienopyridines (Ticlopidine, Clopidogrel, Prasugrel), non-thienopyridines (Cangrelor, Ticagrelor, Elinogrel) and PDE inhibitors (Dipyridamole, Cilostazol) Abciximab (chimeric 7E3 Fab) are used. Therefore, the thrombocytopenia and gastrointestinal bleeding may not be restored by these drugs [230, 231]. Relative to heparin (Table 3C), some well-documented issues are related to its clinical application such as its inefficacy in anti-thrombin deficient patients, bleeding complications and heparin-induced thrombocytopenia as severe side effects [280]. 

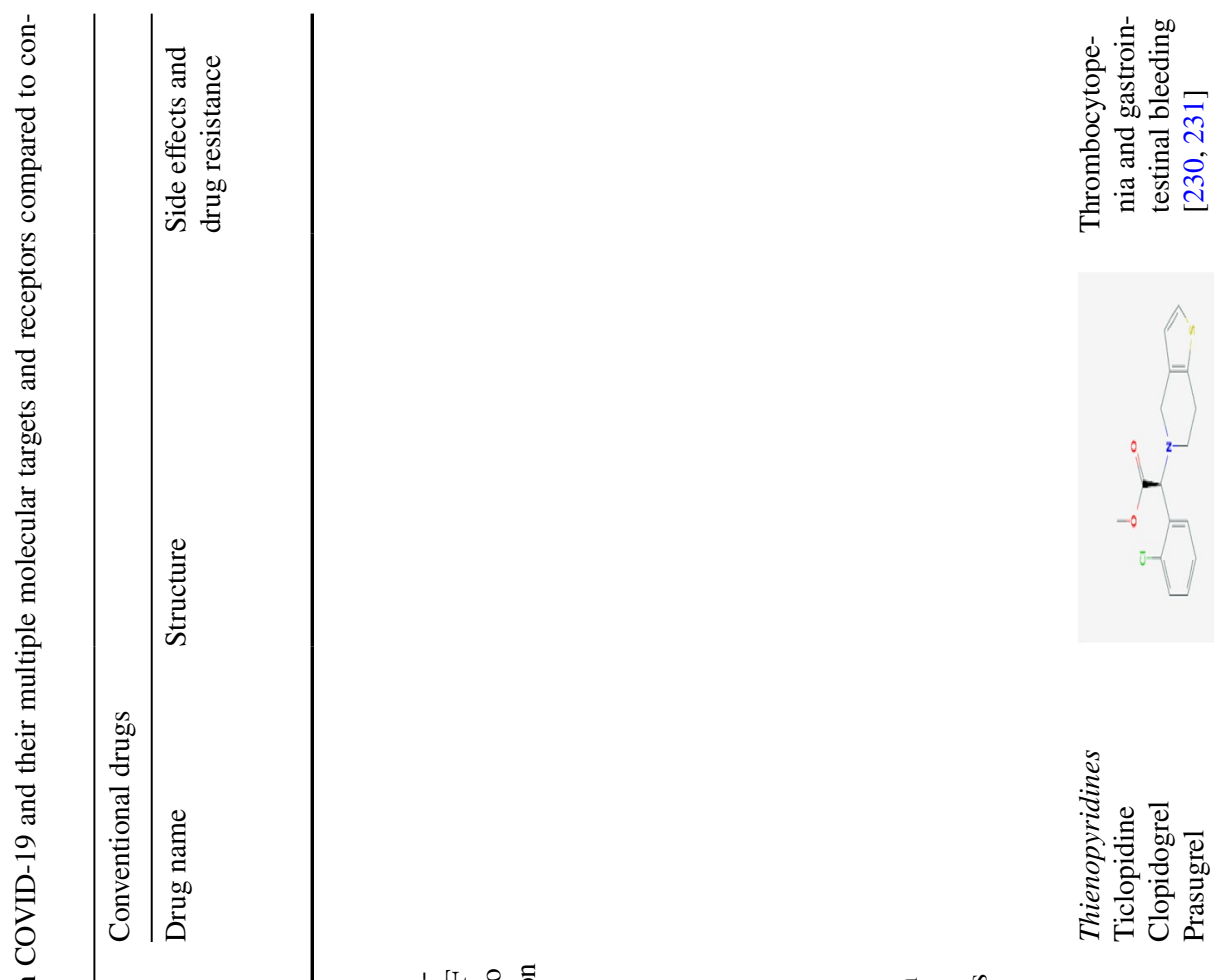


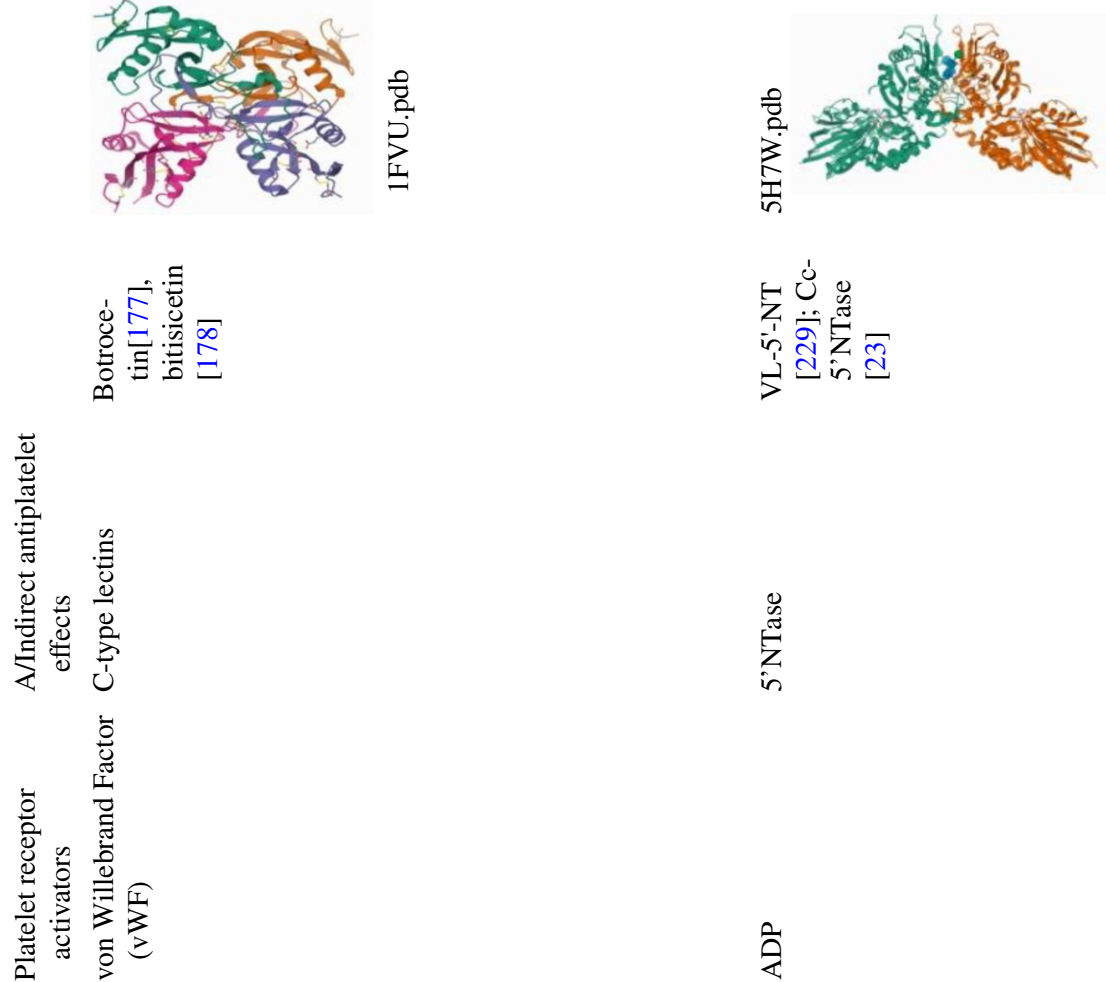

望 Springer 









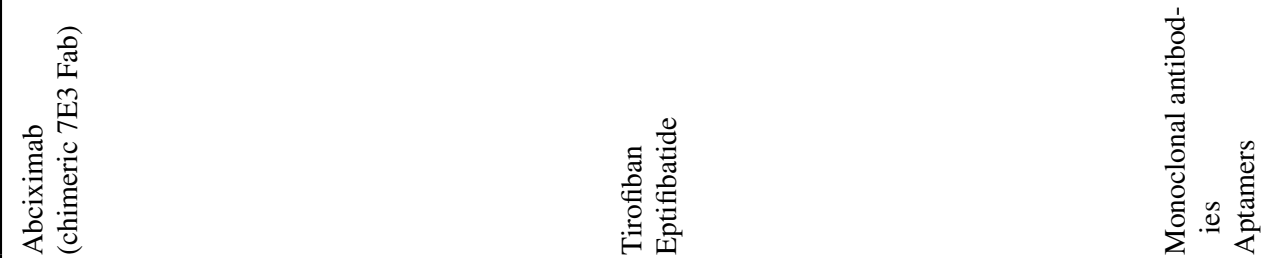


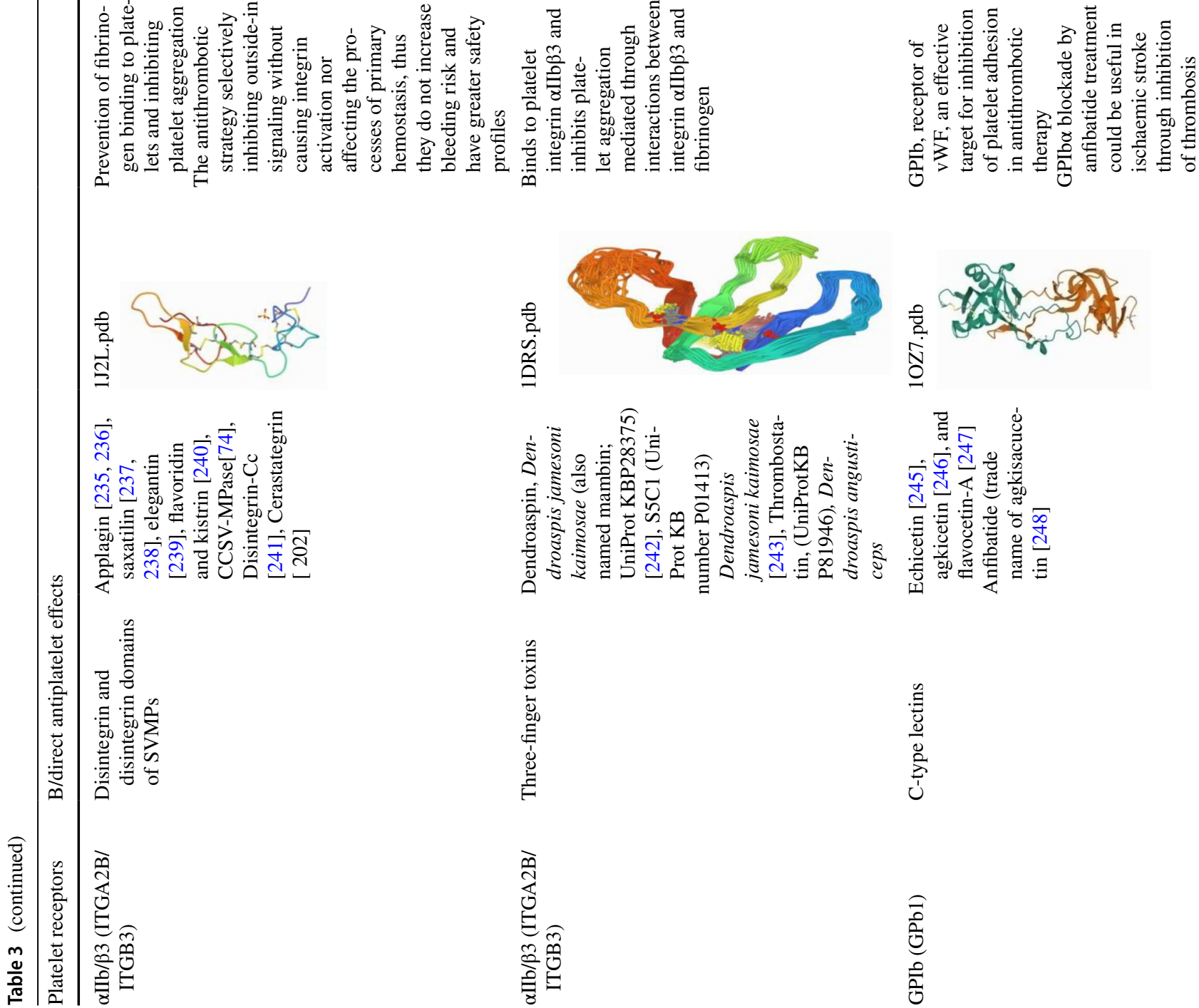

:

泀

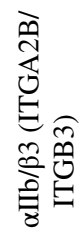

0
0
0
0
0 

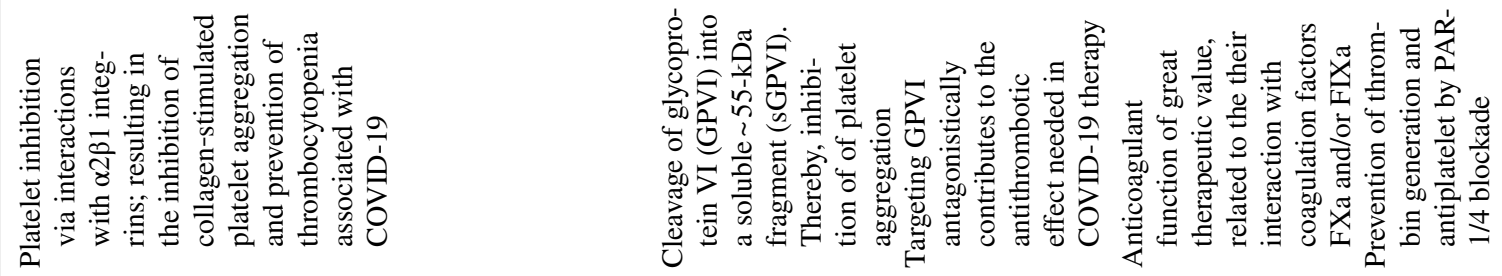

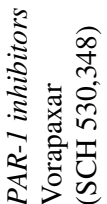


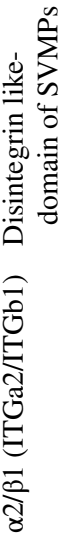
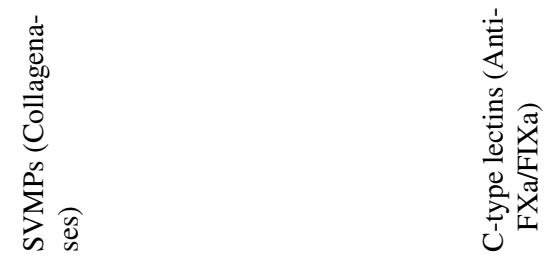

ग

$\underset{\frac{1}{d}}{\frac{1}{a}}$ 


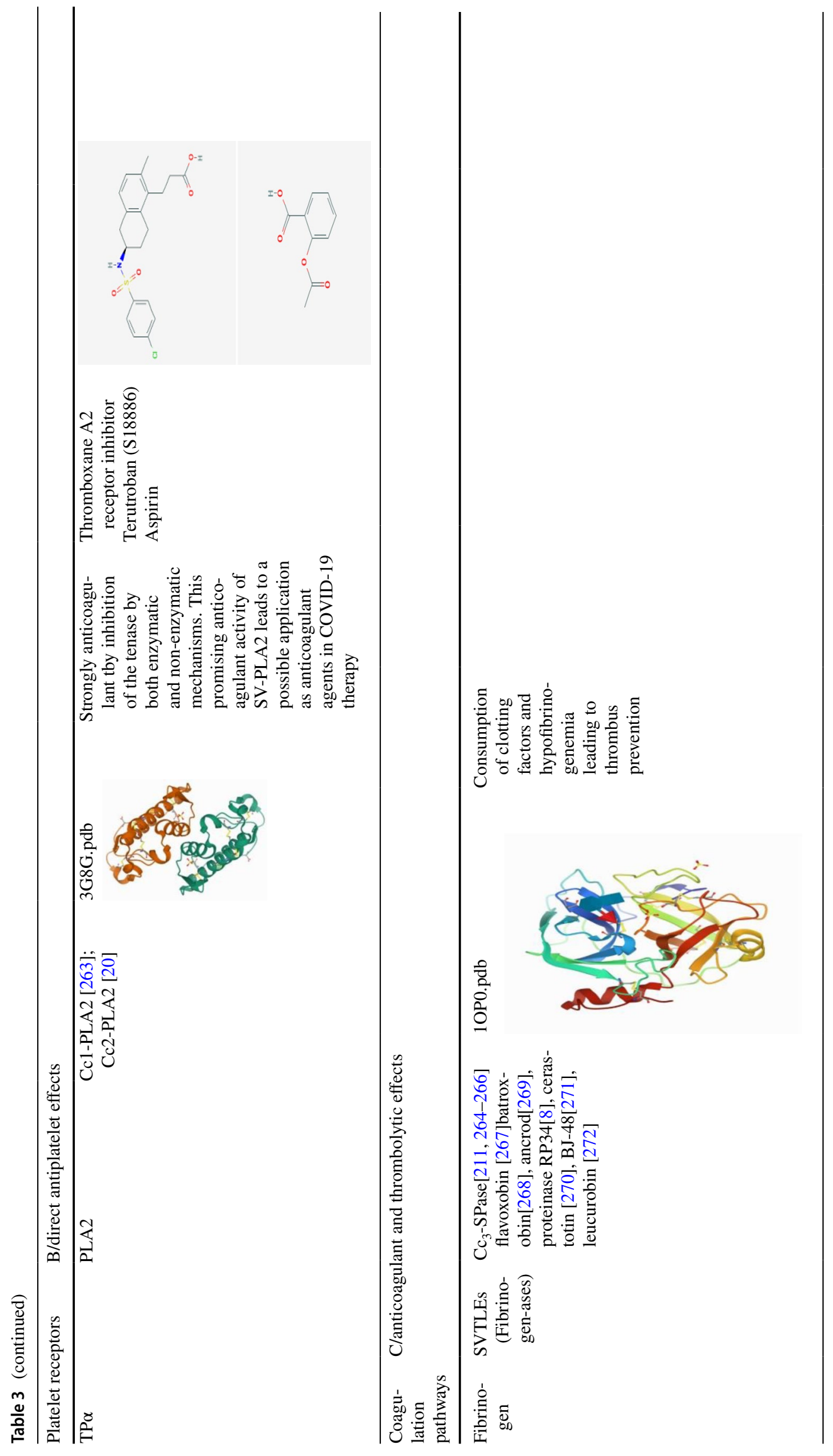

算 Springer 


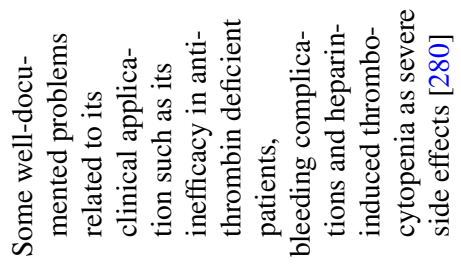


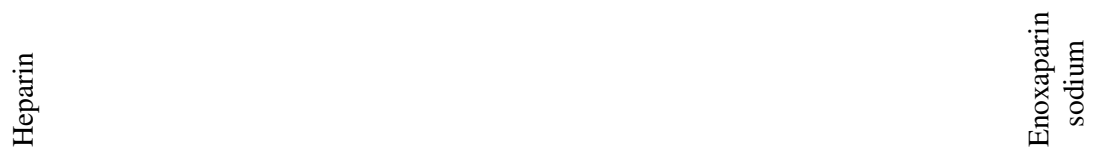

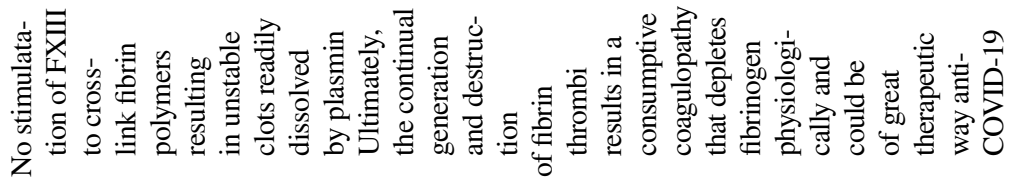



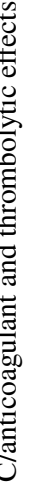

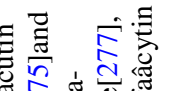

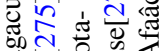

的语



言党穴萠



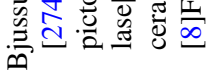

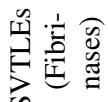

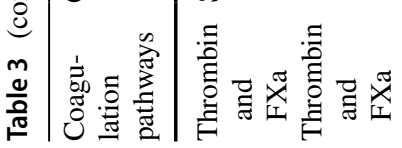




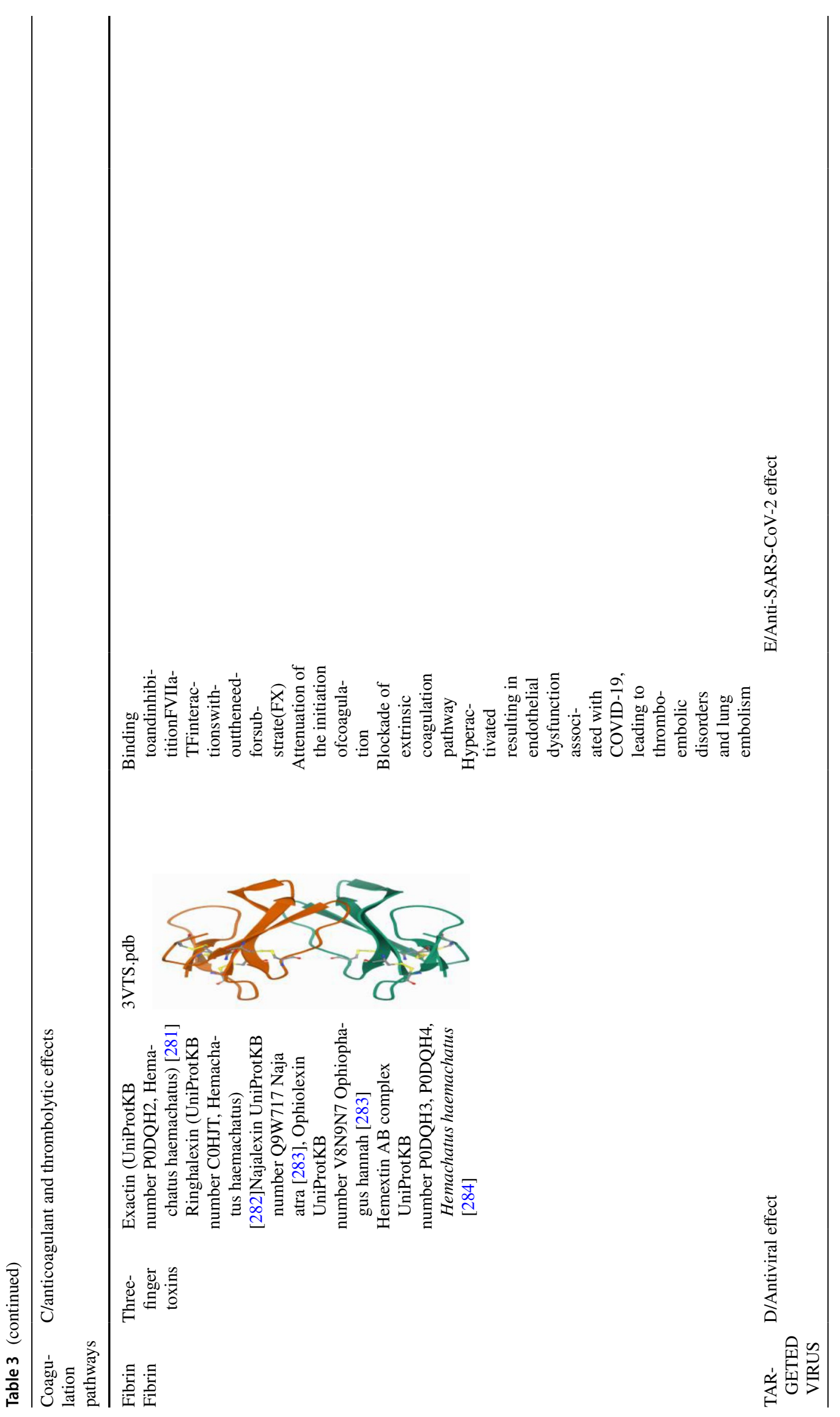




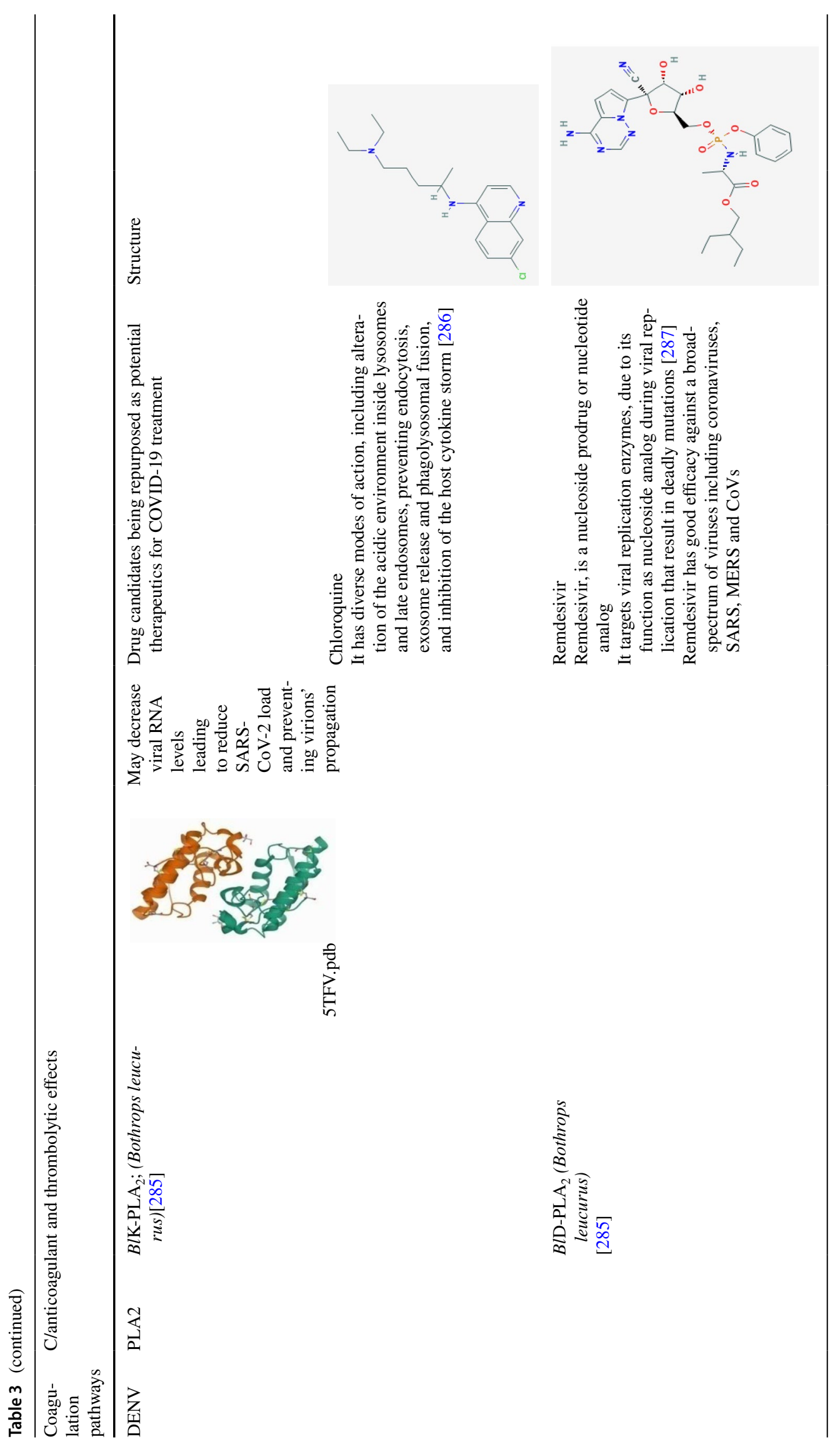




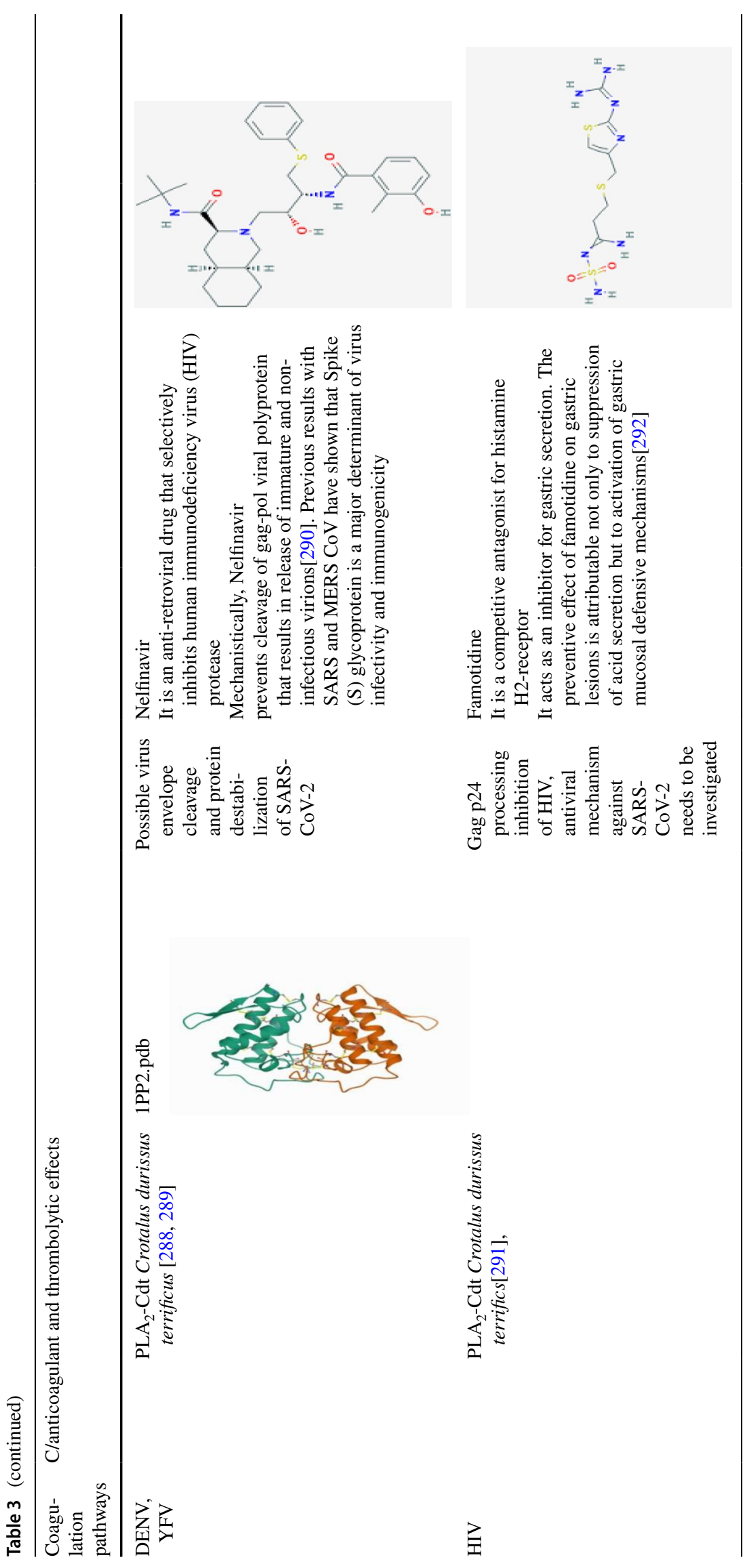

照 Springer 







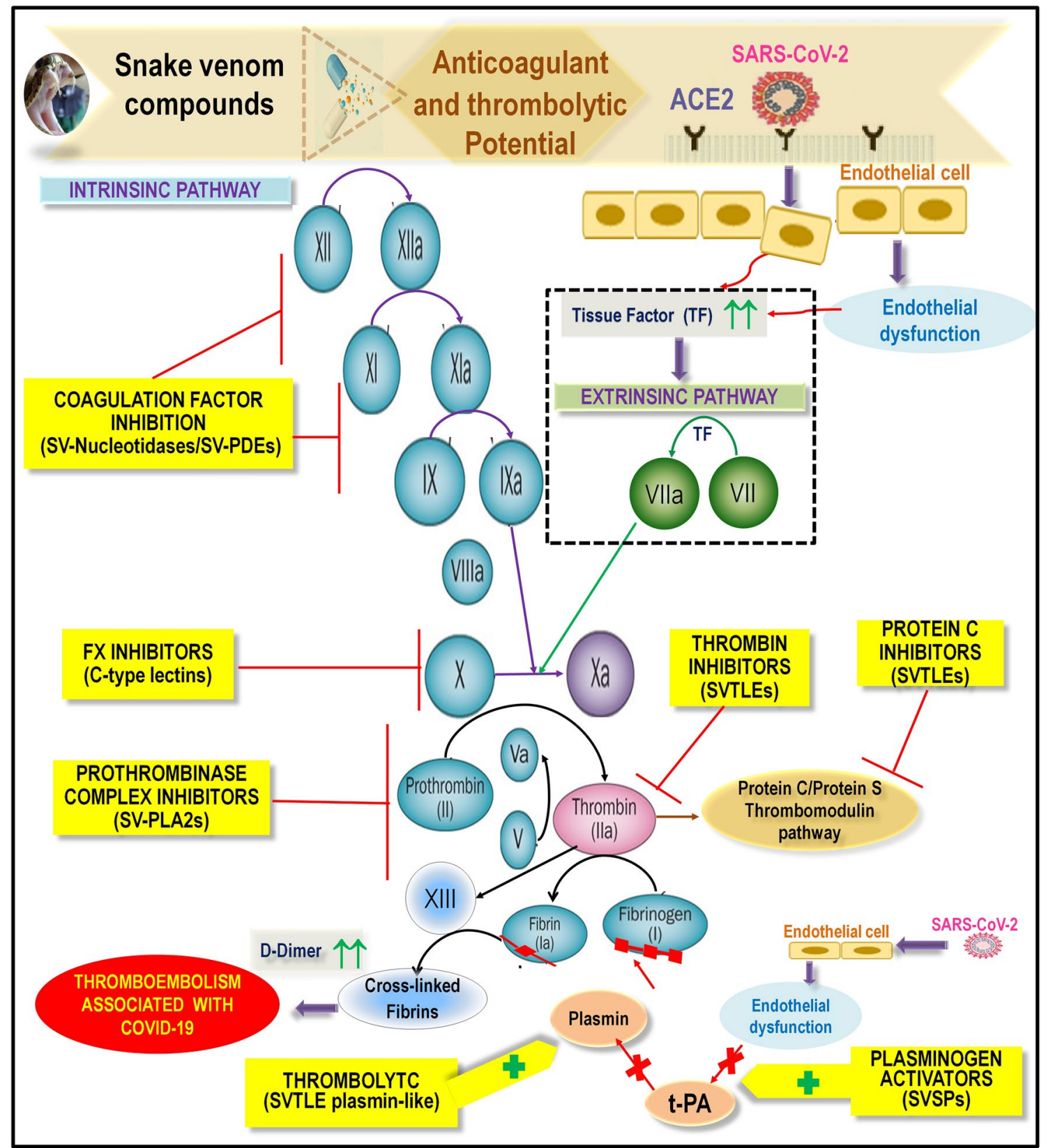

Fig. 7 Potential inhibitory effects of snake venom compounds on coagulopathy associated with COVID-19 and their anti-thrombotic and antiviral mechanism [226, 227]

\section{Conclusion}

This review focused on (i) the comparison of the hemostasis disorders induced by snake venoms with coagulopathy associated with COVID-19, both complications seem to be similar and share several common features; (ii) The use of investigational drugs isolated from snake venoms and the identification of their effective potential as biotherapeutics to treat diseases.
As snake venoms are well-known and the most investigated of all other animal venoms, their bio-compounds are gaining renewed interest as potential sources of new relevant pharmaceutical biotherapeutics and biodiagnostics for human pathologies. The specificity of snake venom proteins and peptides and their bioactivities to target cardiovascular and hemostatic processes make them as promising pharmacological agents. Several compounds derived from snake venoms could be potential candidates as therapeutic and diagnostic agents to COVID-19 pandemic. All of these 
data, alongside current works into components of snake venoms, predict an exciting future for the likely use of snake venom derived-compounds in the field of drug discovery.

Acknowledgements The authors express their gratitude to Dr. Megdad-Lamraoui Amal (USTHB, Faculty of Biological Sciences; Laboratory of Cellular and Molecular Biology) for her kind help and assistance in formatting list of references according to the journal.

Author Contributions Both authors contributed equally to this work, designed the study, provided data and wrote the article.

Funding This research did not receive any specific grant from funding agencies in the public, commercial, or not-for-profit sectors.

\section{Declarations}

Conflict of interest The authors declare that they have no conflict of interest.

\section{References}

1. Piva S, Filippini M, Turla F, Cattaneo S, Margola A, De Fulviis S, Nardiello I, Beretta A, Ferrari L, Trotta R, Erbici G (2020) Clinical presentation and initial management critically ill patients with severe acute respiratory syndrome coronavirus 2 (SARSCoV-2) infection in Brescia, Italy. J Crit Care. 58:29-33

2. Touret F, de Lamballerie X (2020) Of chloroquine and COVID19. Antiviral Res 177:104762

3. Yao X, Ye F, Zhang M, Cui C, Huang B, Niu P, Liu X, Zhao L, Dong E, Song C (2020) In vitro antiviral activity and projection of optimized dosing design of hydroxychloroquine for the treatment of severe acute respiratory syndrome coronavirus 2 (SARS-CoV-2). Clin Infect Dis

4. Gordon CJ, Tchesnokov EP, Woolner E, Perry JK, Feng JY, Porter DP, Götte M (2020) Remdesivir is a direct-acting antiviral that inhibits RNA-dependent RNA polymerase from severe acute respiratory syndrome coronavirus 2 with high potency. J Biol Chem 295:6785-6797. https://doi.org/10.1074/jbc.RA120. 013679

5. Malin JJ, Suárez I, Priesner V, Fätkenheuer G, Rybniker J (2020) Remdesivir against COVID-19 and other viral diseases. Clin Microbiol Rev. 34(1):e00162-20. https://doi.org/10.1128/CMR. 00162-20

6. Tang N, Bai H, Chen X, Gong J, Li D, Sun Z (2020) Anticoagulant treatment is associated with decreased mortality in severe coronavirus disease 2019 patients with coagulopathy. J Thromb Haemost 18(5):1094-1099

7. Vinayagam S, Sattu K (2020) SARS-CoV-2 and coagulation disorders in different organs. Life Sci 118431

8. Suresh PS. Curcumin and Coagulopathy in the COVID19 Era. Indian J Clin Biochem. 2020 Jul 15;35(4):1-2. doi: https://doi. org/10.1007/s12291-020-00914-5.

9. Fatima L, Fatah C (2014) Pathophysiological and pharmacological effects of snake venom components: molecular targets. J Clin Toxicol 4 (190):2161-0495.2190

10. Laraba-Djebari F, Martin-Eauclaire MF, Mauco G, Marchot $P$ (1995) Afaâcytin, an $\alpha \beta$-fibrinogenase from Cerastes cerastes (Horned Viper) Venom, activates purified factor $\mathrm{X}$ and induces serotonin release from human blood platelets. Eur J Biochem 233(3):756-765
11. Rashidi R, Valokola MG, Rad SZK, Etemad L, Roohbakhsh A (2018) Antiplatelet properties of snake venoms: a mini review. Toxin Reviews

12. Torres A, Dantas R, Menezes R, Toyama M, Oliveira M, Nogueira N, Oliveira M, Monteiro H, Martins A (2010) Antimicrobial activity of an L-amino acid oxidase isolated from Bothrops leucurus snake venom. J Venomous Anim Toxins Incl Trop Dis 16(4):614-622

13. Kuna E, Bocian A, Hus KK, Petrilla V, Petrillova M, Legath J, Lewinska A, Wnuk M (2020) Evaluation of antifungal activity of Naja pallida and Naja mossambica venoms against three Candida species. Toxins 12(8):500

14. Ciscotto P, de Avila RM, Coelho EA, Oliveira J, Diniz CG, Farías LM et al (2009) Antigenic, microbicidal and antiparasitic properties of an 1-amino acid oxidase isolated from Bothrops jararaca snake venom. Toxicon 53(3):330-341

15. Ferreira SH, Bartelt DC, Greene LJ (1970) Isolation of bradykinin-potentiating peptides from Bothrops jararaca venom. Biochemistry 9(13):2583-2593

16. Tu AT, Wiley J (1977) Venoms: chemistry and molecular biology

17. Peerlinck K, De Lepeleire I, Goldberg M, Farrell D, Barrett J, Hand E, Panebianco D, Deckmyn H, Vermylen J, Arnout J (1993) MK-383 (L-700,462), a selective nonpeptide platelet glycoprotein IIb/IIIa antagonist, is active in man. Circulation 88(4):1512-1517

18. Fenard D, Lambeau G, Valentin E, Lefebvre J-C, Lazdunski M, Doglio A (1999) Secreted phospholipases A 2, a new class of HIV inhibitors that block virus entry into host cells. J Clin Investig 104(5):611-618

19. Hutton R, Warrell D (1993) Action of snake venom components on the haemostatic system. Blood Rev 7(3):176-189

20. Chérifi F, Namane A, Laraba-Djebari F (2014) Isolation, functional characterization and proteomic identification of CC2-PLA 2 from Cerastes cerastes venom: a basic platelet-aggregationinhibiting factor. Protein J 33(1):61-74

21. Slagboom J, Kool J, Harrison RA, Casewell NR (2017) Haemotoxic snake venoms: their functional activity, impact on snakebite victims and pharmaceutical promise. Br J Haematol 177(6):947-959

22. Tasoulis T, Isbister GK (2017) A review and database of snake venom proteomes. Toxins 9(9):290

23. Saoud S, Chérifi F, Benhassine T, Laraba-Djebari F (2017) Purification and characterization of a platelet aggregation inhibitor and anticoagulant Cc 5_NTase, CD 73-like, from Cerastes cerastes venom. J Biochem Mol Toxicol 31 (5):1885

24. Samah S, Fatah C, Jean-Marc B, Safia K-T, Fatima L-D (2017) Purification and characterization of Cc-Lec, C-type lactosebinding lectin: a platelet aggregation and blood-clotting inhibitor from Cerastes cerastes venom. Int J Biol Macromol 102:336-350

25. Munawar A, Ali SA, Akrem A, Betzel C (2018) Snake venom peptides: tools of biodiscovery. Toxins 10(11):474

26. Labò N, Ohnuki H, Tosato G (2020) Vasculopathy and coagulopathy associated with SARS-CoV-2 infection. Cells 9(7):1583

27. Maduwage K, Isbister GK (2014) Current treatment for venominduced consumption coagulopathy resulting from snakebite. PLoS Negl Trop Dis 8(10):e3220

28. Mohamed Abd El-Aziz T, Soares AG, Stockand JD (2019) Snake venoms in drug discovery: valuable therapeutic tools for life saving. Toxins 11(10):564

29. Gempeler-Messina P, Volz K, Bühler B, Müller C (2001) Protein $\mathrm{C}$ activators from snake venoms and their diagnostic use. Pathophysiol Haemost Thromb 31(3-6):266-272

30. Serrano SM (2013) The long road of research on snake venom serine proteinases. Toxiconomy 62:19-26

31. Lu X, Williams J, Deadman J, Salmon G, Kakkar V, Wilkinson J, Baruch D, Authi K, Rahman S (1994) Preferential antagonism 
of the interactions of the integrin $\alpha$ IIb $\beta 3$ with immobilized glycoprotein ligands by snake-venom RGD (Arg-Gly-Asp) proteins. Evidence supporting a functional role for the amino acid residues flanking the tripeptide RGD in determining the inhibitory properties of snake-venom RGD proteins. Biochem J 304 (3):929-936

32. Silva MB, Schattner M, Ramos CR, Junqueira-de-Azevedo IL, Guarnieri MC, Lazzari MA, Sampaio CA, Pozner RG, Ventura JS, Ho PL (2003) A prothrombin activator from Bothrops erythromelas (jararaca-da-seca) snake venom: characterization and molecular cloning. Biochem J 369(1):129-139

33. Guo YR, Cao QD, Hong ZS et al (2020) The origin, transmission and clinical therapies on coronavirus disease 2019 (COVID-19) outbreak-an update on the status. Mil Med Res 7(1):11. https:// doi.org/10.1186/s40779-020-00240-0

34. https://www.who.int/health-topics/coronavirus\#tab=tab_3

35. Drosten C, Günther S, Preiser W, Van Der Werf S, Brodt H-R, Becker S, Rabenau H, Panning M, Kolesnikova L, Fouchier RA (2003) Identification of a novel coronavirus in patients with severe acute respiratory syndrome. N Engl J Med 348(20):1967-1976

36. Ksiazek TG, Erdman D, Goldsmith CS, Zaki SR, Peret T, Emery S, Tong S, Urbani C, Comer JA, Lim W (2003) A novel coronavirus associated with severe acute respiratory syndrome. N Engl J Med 348(20):1953-1966

37. Zaki AM, Van Boheemen S, Bestebroer TM, Osterhaus AD, Fouchier RA (2012) Isolation of a novel coronavirus from a man with pneumonia in Saudi Arabia. N Engl J Med 367(19):1814-1820

38. Zhou P, Lou YX, Wang X, Hu B, Zhang L (2020) Zhang W A pneumonia outbreak associated with a new coronavirus of probable bat origin. Nature [Internet] 579(7798):270-273

39. Zhu N, Zhang D, Wang W, Li X, Yang B, Song J, Zhao X, Huang B, Shi W, Lu R (2020) A novel coronavirus from patients with pneumonia in China, 2019. New England journal of medicine

40. Huang C, Wang Y, Li X, Ren L, Zhao J, Hu Y, Zhang L, Fan G, Xu J, Gu X (2020) Clinical features of patients infected with 2019 novel coronavirus in Wuhan, China. Lancet 395(10223):497-506

41. World Healthorganization (2020) Flambée de maladie à coronavirus 2019 (COVID-19). Search. https://www.who.int/. Accessed 22 Nov 2020

42. Shah SH, Moore E, Robertson C, McMenamin J, Katikireddi SV, Simpson CR et al (2021) Predicted COVID-19 positive cases, hospitalisations, and deaths associated with the Delta variant of concern, June-July, 2021, Lancet Digit Health 2021 Published Online August 9, 2021 https://doi.org/10.1016/S2589-7500(21) 00175-8

43. Zhang H, Penninger JM, Li Y, Zhong N, Slutsky AS (2020) Angiotensin-converting enzyme 2 (ACE2) as a SARS-CoV-2 receptor: molecular mechanisms and potential therapeutic target. Intens Care Med 46(4):586-590. https://doi.org/10.1007/ s00134-020-05985-9

44. Tipnis SR, Hooper NM, Hyde R, Karran E, Christie G, Turner AJ (2000) A human homolog of angiotensin-converting enzyme cloning and functional expression as a captopril-insensitive carboxypeptidase. J Biol Chem 275(43):33238-33243

45. Hu B, Zeng L-P, Yang X-L, Ge X-Y, Zhang W, Li B, Xie J-Z, Shen X-R, Zhang Y-Z, Wang N (2017) Discovery of a rich gene pool of bat SARS-related coronaviruses provides new insights into the origin of SARS coronavirus. PLoS Pathogens 13(11):e1006698

46. Li W, Shi Z, Yu M, Ren W, Smith C, Epstein JH, Wang H, Crameri G, Hu Z, Zhang H (2005) Bats are natural reservoirs of SARS-like coronaviruses. Science 310(5748):676-679

47. Wang M, Yan M, Xu H, Liang W, Kan B, Zheng B, Chen H, Zheng H, Xu Y, Zhang E (2005) SARS-CoV infection in a restaurant from palm civet. Emerg Infect Dis 11(12):1860
48. Liu DX, Liang JQ, Fung TS (2020) Human coronavirus-229E,OC43,-NL63, and-HKU1. Reference Module Life Sci. B978-0

49. Ke Z, Oton J, Qu K et al (2020) Structures and distributions of SARS-CoV-2 spike proteins on intact virions. Nature 588:498502. https://doi.org/10.1038/s41586-020-2665-2

50. Spiga O, Bernini A, Ciutti A, Chiellini S, Menciassi N, Finetti F, Causarono V, Anselmi F, Prischi F, Niccolai N (2003) Molecular modelling of S1 and S2 subunits of SARS coronavirus spike glycoprotein. Biochem Biophys Res Commun 310(1):78-83

51. V'kovski P, Kratzel A, Steiner S, Stalder H, Thiel V (2021) Coronavirus biology and replication: implications for SARS-CoV-2. Nat Rev Microbiol 19(3):155-70

52. Sarma P, Shekhar N, Prajapat M, Avti P, Kaur H, Kumar S, Singh S, Kumar H, Prakash A, Dhibar DP, Medhi B (2021) In-silico homology assisted identification of inhibitor of RNA binding against 2019-nCoV N-protein ( $\mathrm{N}$ terminal domain). J Biomol Struct Dyn 39(8):2724-32

53. Ruch TR, Machamer CE (2012) The coronavirus E protein: assembly and beyond. Viruses 4(3):363-382

54. Schoeman D, Fielding BC (2019) Coronavirus envelope protein: current knowledge. Virol J 16(1):1-22

55. Ciulla MM (2020) SARS-CoV-2 downregulation of ACE2 and pleiotropic effects of ACEIs/ARBs. Hypertens Res 43(9):985-986

56. van de Veerdonk FL, Netea MG, van Deuren M, van der Meer JW, de Mast Q, Brüggemann RJ, van der Hoeven H (2020) Kallikrein-kinin blockade in patients with COVID-19 to prevent acute respiratory distress syndrome. Elife 9:e57555

57. Zambelli V, Bellani G, Borsa R, Pozzi F, Grassi A, Scanziani M, Castiglioni V, Masson S, Decio A, Laffey JG (2015) Angiotensin-(1-7) improves oxygenation, while reducing cellular infiltrate and fibrosis in experimental Acute Respiratory Distress Syndrome. Intens Care Med Exp 3(1):1-17

58. Kuba K, Imai Y, Rao S, Jiang C, Penninger JM (2006) Lessons from SARS: control of acute lung failure by the SARS receptor ACE2. J Mol Med 84(10):814-820

59. Green SJ (2020) Covid-19 accelerates endothelial dysfunction and nitric oxide deficiency. Microbes Infect 22(4):149

60. Ozdemir B, Yazici A (2020) Could the decrease in the endothelial nitric oxide (NO) production and $\mathrm{NO}$ bioavailability be the crucial cause of COVID-19 related deaths? Med Hypotheses 144:109970

61. Horby P, Huntley C, Davies N, Edmunds J, Ferguson N, Medley G, Hayward A, Cevik M, Semple C (2021) NERVTAG note on B. 1.1. 7 severity. New \& Emerging Threats Advisory Group, Jan 21

62. National Institute of Infectious Diseases J (2021) Brief report: New Variant Strain of SARS-CoV-2 Identified in Travelers from Brazil [Press release]. Retrieved from https://www.niid.go.jp/ niid/en/2019-ncov-e/10108-covid19-33-en.htmlexternal icon. Accessed 18 Feb 2020

63. Resende PC, Bezerra JF, de Vasconcelos RHT, Arantes I, Appolinario L, Mendonça AC, Paixao AC, Rodrigues ACD, Silva T, Rocha AS Spike E484K mutation in the first SARS-CoV-2 reinfection case confirmed in Brazil, 2020.

64. Zhou B, Thao TTN, Hoffmann D, Taddeo A, Ebert N, Labroussaa F, Pohlmann A, King J, Portmann J, Halwe NJ (2020) SARSCoV-2 spike D614G variant confers enhanced replication and transmissibility. bioRxiv

65. McCarthy KR, Rennick LJ, Nambulli S, Robinson-McCarthy LR, Bain WG, Haidar G (2021) Duprex WP (2021) Recurrent deletions in the SARS-CoV-2 spike glycoprotein drive antibody escape. Science 371(6534):1139-1142. https://doi.org/10.1126/ science.abf6950

66. Kemp S, Harvey W, Datir R, Collier D, Ferreira I, Carabelii A, Robertson DL, Gupta RK (2020) Recurrent emergence and 
transmission of a SARS-CoV-2 Spike deletion $\Delta \mathrm{H} 69 / \mathrm{V} 70$. bioRxiv

67. Gutiérrez JM, Calvete JJ, Habib AG, Harrison RA, Williams DJ, Warrell DA (2017) Snakebite envenoming. Nat Rev Dis Primers 3(1): $1-21$

68. World Health organization (2018) Neglected tropical diseases. http://www.who.int/neglected_diseases/en/. Accessed 2019

69. Kasturiratne A, Wickremasinghe AR, de Silva N, Gunawardena NK, Pathmeswaran A, Premaratna R, Savioli L, Lalloo DG, de Silva HJ (2008) The global burden of snakebite: a literature analysis and modelling based on regional estimates of envenoming and deaths. PLoS Med 5(11):e218

70. Harrison RA, Gutiérrez JM (2016) Priority actions and progress to substantially and sustainably reduce the mortality, morbidity and socioeconomic burden of tropical snakebite. Toxins 8(12):351

71. Harrison RA, Casewell NR, Ainsworth SA, Lalloo DG (2019) The time is now: a call for action to translate recent momentum on tackling tropical snakebite into sustained benefit for victims. Trans R Soc Trop Med Hyg 113(12):835-838

72. Zelanis A, Tashima AK (2014) Unraveling snake venom complexity with 'omics' approaches: challenges and perspectives. Toxiconomy 87:131-134

73. Kini RM, Koh CY (2016) Metalloproteases affecting blood coagulation, fibrinolysis and platelet aggregation from snake venoms: Definition and nomenclature of interaction sites. Toxins 8(10):284

74. Chérifi F, Rousselle J-C, Namane A, Laraba-Djebari F (2010) CCSV-MPase, a novel procoagulant metalloproteinase from Cerastes cerastes venom: purification, biochemical characterization and protein identification. Protein J 29(7):466-474

75. Isbister GK, Scorgie F, O'leary M, Seldon M, Brown SG, Lincz L, INVESTIGATORS A (2010) Factor deficiencies in venominduced consumption coagulopathy resulting from Australian elapid envenomation: Australian Snakebite Project (ASP-10). J Thromb Haemost 8(11):2504-2513

76. Gutiérrez JM, Escalante T, Rucavado A, Herrera C (2016) Hemorrhage caused by snake venom metalloproteinases: a journey of discovery and understanding. Toxins 8(4):93

77. Mosquera A, Idrovo LA, Tafur A, Del Brutto OH (2003) Stroke following Bothrops spp. snakebite. Neurology 60(10):1577-1580

78. Phillips DJ, Swenson SD, Francis S, Markland J, Mackessy S (2010) Thrombin-like snake venom serine proteinases. Handbook of Venoms and Toxins of Reptiles 139:154

79. Rosing J, Tans G (2010) Snake venom prothrombin activatorsthe history. In: Toxins and hemostasis. Springer, New York, pp 485-499

80. Joseph JS, Kini RM (2001) Snake venom prothrombin activators homologous to blood coagulation factor Xa. Pathophysiol Haemost Thromb 31(3-6):234-240

81. Rosing J, Govers-Riemslag JW, Yukelson L, Tans G (2001) Factor $\mathrm{V}$ activation and inactivation by venom proteases. Pathophysiol Haemost Thromb 31(3-6):241-246

82. Tans G, Rosing J (2001) Snake venom activators of factor X: an overview. Pathophysiol Haemost Thromb 31(3-6):225-233

83. Swenson S, Markland F Jr (2005) Snake venom fibrin (ogen) olytic enzymes. Toxiconomy 45(8):1021-1039

84. Sanchez EF, Felicori LF, Chavez-Olortegui C, Magalhaes HB, Hermogenes AL, Diniz MV, LM de Junqueira-de-Azevedo I, Magalhaes A, Richardson M (2006) Biochemical characterization and molecular cloning of a plasminogen activator proteinase (LV-PA) from bushmaster snake venom. Biochim Biophys Acta BBA 1760 (12):1762-1771

85. Mebs D, Holada K, Simák J, Vanková H, Müller D, Schoenemann H, Lange H, Herrmann H (1998) Severe coagulopathy after a bite of a green bush viper (Atheris squamiger): case report and biochemical analysis of the venom. Toxiconomy 36(10): $1333-1340$

86. Top L, Tulleken J, Ligtenberg J, Meertens J, Van der Werf T, Zijlstra J (2006) Serious envenomation after a snakebite by a Western bush viper (Atheris chlorechis) in the Netherlands: a case report. Neth J Med 64(5):153-156

87. Hatten BW, Bueso A, French LK, Hendrickson RG, Horowitz BZ (2013) Envenomation by the great lakes bush viper (Atheris nitschei). Clin Toxicol 51(2):114-116

88. Lifshitz M, Kastel H, Harman-Boehm I (2002) Cerastes cerastes envenomation in an 18 year old female: a case report. Toxiconomy 40(8):1227-1229

89. Schneemann M, Cathomas R, Laidlaw S, El Nahas A, Theakston RDG, Warrell DA (2004) Life-threatening envenoming by the Saharan horned viper (Cerastes cerastes) causing micro-angiopathic haemolysis, coagulopathy and acute renal failure: clinical cases and review. QJM 97(11):717-727

90. Valenta J, Stach Z, Fricova D, Zak J, Balik M (2008) Envenoming by the viperid snake Proatheris superciliaris: a case report. Toxiconomy 52(2):392-394

91. Jennings B, Spearman C, Kirsch R, Shephard E (1999) A novel high molecular weight fibrinogenase from the venom of Bitis arietans. Biochim Biophys Acta BBA 1427(1):82-91

92. Warrell D, Ormerod L, Davidson NM (1975) Bites by puff-adder (Bitis arietans) in Nigeria, and value of antivenom. Br Med J 4(5998):697-700

93. Lavonas EJ, Tomaszewski CA, Ford MD, Rouse AM, Kerns WP II (2002) Severe puff adder (Bitis arietans) envenomation with coagulopathy. J Toxicol Clin Toxicol 40(7):911-918

94. McNally T, Conway G, Jackson L, Theakston RDG, Marsh N, Warrell D, Young L, Mackie I, Machin S (1993) Accidental envenoming by a Gaboon viper (Bitis gabonica): the haemostatic disturbances observed and investigation of in vitro haemostatic properties of whole venom. Trans R Soc Trop Med Hyg 87(1):66-70

95. Porath A, Gilon D, Schulchynska-Castel H, Shalev O, Keynan A, Benbassat J (1992) Risk indicators after envenomation in humans by Echis coloratus (mid-east saw scaled viper). Toxiconomy 30(1):25-32

96. Mann G (1978) Echis colorata bites in Israel: an evaluation of specific antiserum use on the base of 21 cases of snake bite. Toxicol Eur Res 1(6):365-369

97. Warrell D, Davidson NM, Greenwood B, Ormerod L, Pope HM, Watkins BJ, Prentice C (1977) Poisoning by bites of the saw-scaled or carpet viper (Echis carinatus) in Nigeria. QJM 46(1):33-62

98. Mion G, Larréché S, Benois A, Petitjeans F, Puidupin M (2013) Hemostasis dynamics during coagulopathy resulting from Echis envenomation. Toxiconomy 76:103-109

99. Gillissen A, Theakston RDG, Barth J, May B, Krieg M, Warrell DA (1994) Neurotoxicity, haemostatic disturbances and haemolytic anaemia after a bite by a Tunisian saw-scaled or carpet viper (Echis 'pyramidum'-complex): failure of antivenom treatment. Toxiconomy 32(8):937-944

100. Aitchison J (1990) Boomslang bite—diagnosis and management. A report of 2 cases. S Afr Med J 78(1):39-42

101. Phillips RE, Theakston RDG, Warrell DA, Galigedara Y, Abeysekera D, Dissanayaka P, Hutton RA, Aloysius DJ (1988) Paralysis, rhabdomyolysis and haemolysis caused by bites of Russell's viper (Vipera russelli pulchella) in Sri Lanka: failure of Indian (Haffkine) antivenom. QJM 68(3-4):691-715

102. Isbister G, Maduwage $\mathrm{K}$, Shahmy S, Mohamed F, Abeysinghe $\mathrm{C}$, Karunathilake H, Ariaratnam C, Buckley N (2013) Diagnostic 20-min whole blood clotting test in Russell's viper envenoming delays antivenom administration. QJM 106(10):925-932 
103. Than T, Hutton R, Lwin M, Han KE, Soe S, Swe TN, Phillips R, Warrell D (1988) Haemostatic disturbances in patients bitten by Russell's viper (Vipera russelli siamensis) in Burma. Br J Haematol 69(4):513-520

104. Maduwage K, Scorgie F, Silva A, Shahmy S, Mohamed F, Abeysinghe C, Karunathilake H, Lincz L, Gnanathasan CA, Isbister G (2013) Hump-nosed pit viper (Hypnale hypnale) envenoming causes mild coagulopathy with incomplete clotting factor consumption. Clin Toxicol 51(7):527-531

105. Kularatne S, Sivansuthan S, Medagedara S, Maduwage K, de Silva A (2011) Revisiting saw-scaled viper (Echis carinatus) bites in the Jaffna Peninsula of Sri Lanka: distribution, epidemiology and clinical manifestations. Trans R Soc Trop Med Hyg 105(10):591-597

106. Warrell DA, Looareesuwan S, Theakston RDG, Phillips RE, Chanthavanich P, Viravan C, Supanaranond W, Karbwang J, Ho M, Hutton RA (1986) Randomized comparative trial of three monospecific antivenoms for bites by the Malayan pit viper ( $\mathrm{Cal}$ loselasma rhodostoma) in southern Thailand: clinical and laboratory correlations. Am J Trop Med Hyg 35(6):1235-1247

107. Hutton R, Looareesuwan S, Ho M, Silamut K, Chanthavanich P, Karbwang J, Supanaranond W, Vejcho S, Viravan C, Phillips R (1990) Arboreal green pit vipers (genus Trimeresurus) of South-East Asia: bites by T. albolabris and T. macrops in Thailand and a review of the literature. Trans R Soc Trop Med Hyg 84(6):866-874

108. Rojnuckarin P, Intragumtornchai T, Sattapiboon R, Muanpasitporn C, Pakmanee N, Khow O, Swasdikul D (1999) The effects of green pit viper (Trimeresurus albolabris and Trimeresurus macrops) venom on the fibrinolytic system in human. Toxiconomy 37(5):743-755

109. Li Q-B, Huang G-W, Kinjoh K, Nakamura M, Kosugi T (2001) Hematological studies on DIC-like findings observed in patients with snakebite in south China. Toxiconomy 39(7):943-948

110. Mori K, Hisa S, Suzuki S, Sugai K, Sakai H, Kikuchi T, Hiwatashi N, Shishido H, Goto Y, Takahashi T (1983) A case of severe defibrination syndrome due to snake (Rhabdophis tigrinus) bite. Jpn J Clin Hematol 24(3):256

111. Isbister GK Snakebite doesn't cause disseminated intravascular coagulation: coagulopathy and thrombotic microangiopathy in snake envenoming. In: Seminars in thrombosis and hemostasis, 2010. (C) Thieme Medical Publishers, pp 444-451

112. Pardal PPdO, Souza SM, Monteiro MRdCdC, Fan HW, Cardoso JLC, França FOS, Tomy SC, Sano-Martins IS, de Sousa-e-Silva MCC, Colombini M (2004) Clinical trial of two antivenoms for the treatment of Bothrops and Lachesis bites in the north eastern Amazon region of Brazil. Trans R Soc Trop Med Hyg 98(1):28-42

113. Otero-Patiño R, Segura Á, Herrera M, Angulo Y, León G, Gutiérrez JM, Barona J, Estrada S, Pereañez A, Quintana JC (2012) Comparative study of the efficacy and safety of two polyvalent, caprylic acid fractionated [IgG and $\mathrm{F}\left(\mathrm{ab}^{\prime}\right)$ 2] antivenoms. Bothrops asper bites in Colombia Toxicon 59(2):344-355

114. Kamiguti A, Matsunaga S, Spir M, Sano-Martins I, Nahas L (1986) Alterations of the blood coagulation system after accidental human inoculation by Bothrops jararaca venom. Braz $\mathrm{J}$ Med Biol Res 19(2):199-204

115. Budzynski AZ, Pandya BV, Rubin RN, Brizuela BS, Soszka T, Stewart G (1984) Fibrinogenolytic afibrinogenemia after envenomation by western diamondback rattlesnake (Crotalus atrox)

116. Kitchens CS, Eskin TA (2008) Fatality in a case of envenomation by Crotalus adamanteus initially successfully treated with polyvalent ovine antivenom followed by recurrence of defibrinogenation syndrome. J Med Toxicol 4(3):180-183

117. Hardy DL, Jeter M, Corrigan JJ Jr (1982) Envenomation by the northern blacktail rattlesnake (Crotalus molossus molossus): report of two cases and the vitro effects of the venom on fibrinolysis and platelet aggregation. Toxiconomy 20(2):487-493

118. Hasiba U, Rosenbach LM, Rockwell D, Lewis JH (1975) DIClike syndrome after envenomation by the snake, Crotalus horridus horridus. N Engl J Med 292(10):505-507

119. Bush SP, Green SM, Moynihan JA, Hayes WK, Cardwell MD (2002) Crotalidae polyvalent immune Fab (ovine) antivenom is efficacious for envenomations by Southern Pacific rattlesnakes (Crotalus helleri). Ann Emerg Med 40(6):619-624

120. Petite J (2005) Viper bites: treat or ignore? Swiss Med Wkly 135 (4142)

121. Boels D, Hamel JF, Deguigne MB, Harry P (2012) European viper envenomings: Assessment of Viperfa ${ }^{\mathrm{TM}}$ and other symptomatic treatments. Clin Toxicol 50(3):189-196

122. Lukšić B, Čulić V, Stričević L, Brizić I, Poljak NK, Tadić Z (2010) Infant death after nose-horned viper (Vipera ammodytes ammodytes) bite in Croatia: a case report. Toxicon 56(8):1506-1509

123. Sotelo N (2008) Review of treatment and complications in 79 children with rattlesnake bite. Clin Pediatr 47(5):483-489

124. Brown SG, Caruso N, Borland ML, McCoubrie DL, Celenza A, Isbister GK (2009) Clotting factor replacement and recovery from snake venom-induced consumptive coagulopathy. Intens Care Med 35(9):1532-1538

125. Kini RM (2005) The intriguing world of prothrombin activators from snake venom. Toxiconomy 45(8):1133-1145

126. Murakami MT, Arni RK (2005) Thrombomodulin-independent activation of protein $\mathrm{C}$ and specificity of hemostatically active snake venom serine proteinases crystal structures of native and inhibited Agkistrodon contortrix contortrix protein c activator. J Biol Chem 280(47):39309-39315

127. Yip J, Shen Y, Berndt MC, Andrews RK (2005) Primary platelet adhesion receptors. IUBMB Life 57(2):103-108

128. Kini RM (2006) Anticoagulant proteins from snake venoms: structure, function and mechanism. Biochem J 397(3):377-387

129. Kang TS, Georgieva D, Genov N, Murakami MT, Sinha M, Kumar RP, Kaur P, Kumar S, Dey S, Sharma S (2011) Enzymatic toxins from snake venom: structural characterization and mechanism of catalysis. FEBS J 278(23):4544-4576

130. Chakrabarty D, Chanda C (2015) Snake venom disintegrins. In: Gopalkrishnakone P (ED) Snake venoms. pp 1-11

131. Warrell DA (1995) Clinical toxicology of snakebite in Africa and the Middle East/Arabian Peninsula. Handbook of clinical toxicology of animal venoms and poisons. CRC Press, Boca Raton, pp 433-492

132. Rucavado A, Soto M, Escalante T, Loría GD, Arni R, Gutiérrez JM (2005) Thrombocytopenia and platelet hypoaggregation induced by Bothrops asper snake venom. Thromb Haemost 94(07):123-131

133. Camargo AC, Ianzer D, Guerreiro JR, Serrano SM (2012) Bradykinin-potentiating peptides: beyond captopril. Toxiconomy 59(4):516-523

134. Guzik TJ, Mohiddin SA, Dimarco A, Patel V, Savvatis K, Marelli-Berg FM, Madhur MS, Tomaszewski M, Maffia P, D'acquisto F, Nicklin SA (2020) COVID-19 and the cardiovascular system: implications for risk assessment, diagnosis, and treatment options. Cardiovasc Res 116(10):1666-1687

135. Nishiga M, Wang DW, Han Y, Lewis DB, Wu JC (2020) COVID19 and cardiovascular disease: from basic mechanisms to clinical perspectives. Nat Rev Cardiol 17(9):543-558

136. Ye Z, Zhang Y, Wang Y, Huang Z, Song B (2020) Chest CT manifestations of new coronavirus disease 2019 (COVID-19): a pictorial review. Eur Radiol 30(8):4381-9

137. Guan W, Ni Z, Hu Y, Liang W, Ou C, He J, Liu L, Shan H, Lei C, Hui D (2019) China Medical Treatment Expert Group for Covid19. Clinical characteristics of coronavirus disease, pp 1708-1720 
138. Tang N, Li D, Wang X, Sun Z (2020) Abnormal coagulation parameters are associated with poor prognosis in patients with novel coronavirus pneumonia. J Thromb Haemost 18(4):844-847

139. Barnes GD, Burnett A, Allen A, Blumenstein M, Clark NP, Cuker A, Dager WE, Deitelzweig SB, Ellsworth S, Garcia D, Kaatz S (2020) Thromboembolism and anticoagulant therapy during the COVID-19 pandemic: interim clinical guidance from the anticoagulation forum. J Thromb Thromb 50:72-81

140. Giannis D, Ziogas IA, Gianni P (2020) Coagulation disorders in coronavirus infected patients: COVID-19, SARS-CoV-1, MERS$\mathrm{CoV}$ and lessons from the past. J Clin Virol 127:104362

141. Buisson LS (2020) Coagulopathie associée au COVID-19: les éléments essentiels pour l'anesthésiste-réanimateur. Le Praticien en anesthésie réanimation 24(4):190-195

142. Rajendran P, Rengarajan T, Thangavel J, Nishigaki Y, Sakthisekaran D, Sethi G, Nishigaki I (2013) The vascular endothelium and human diseases. Int J Biol Sci 9(10): 1057

143. Henry BM, Vikse J, Benoit S, Favaloro EJ, Lippi G (2020) Hyperinflammation and derangement of renin-angiotensin-aldosterone system in COVID-19: A novel hypothesis for clinically suspected hypercoagulopathy and microvascular immunothrombosis. Clinica Chimica Acta

144. Merdji H, L Sattler, S Cunat, F Meziani, J Helms - 2021, Hémostase et COVID-19, Médecine Intensive2021 - revue-mir.srlf.org https://doi.org/10.37051/mir-00062

145. Kwaan HC (2020) Coronavirus disease 2019: the role of the fibrinolytic system from transmission to organ injury and sequelae. In: Seminars in thrombosis and hemostasis. Thieme Medical Publishers, pp 841-844

146. Bautista-Vargas M, Bonilla-Abadía F, Cañas CA (2020) Potential role for tissue factor in the pathogenesis of hypercoagulability associated with in COVID-19. J Thromb Thromb 50:479-483

147. Nossent JC, Raymond WD, Eilertsen GØ (2016) Increased von Willebrand factor levels in patients with systemic lupus erythematosus reflect inflammation rather than increased propensity for platelet activation. Lupus Sci Med 3(1):162

148. Fara A, Mitrev Z, Rosalia RA, Assas BM (2020) Cytokine storm and COVID-19: a chronicle of pro-inflammatory cytokines. Open Biol 10(9):200160

149. Stoll D, Yokota R, Sanches Aragão D, Casarini DE (2019) Both aldosterone and spironolactone can modulate the intracellular ACE/ANG II/AT1 and ACE2/ANG (1-7)/MAS receptor axes in human mesangial cells. Physiol Rep 7(11):e14105

150. Sawathiparnich P, Kumar S, Vaughan DE, Brown NJ (2002) Spironolactone abolishes the relationship between aldosterone and plasminogen activator inhibitor-1 in humans. J Clin Endocrinol Metab 87(2):448-452

151. Brown NJ, Agirbasli MA, Williams GH, Litchfield WR, Vaughan DE (1998) Effect of activation and inhibition of the renin-angiotensin system on plasma PAI-1. Hypertension 32(6):965-971

152. Rondina MT, Guo L (2019) The era of thromboinflammation: platelets are dynamic sensors and effector cells during infectious diseases. Front Immunol 10:2204

153. Jackson SP, Darbousset R, Schoenwaelder SM (2019) Thromboinflammation: challenges of therapeutically targeting coagulation and other host defense mechanisms. Blood 133(9):906-918

154. Santamarina MG, Boisier D, Contreras R, Baque M, Volpacchio M, Beddings I (2020) COVID-19: a hypothesis regarding the ventilation-perfusion mismatch. BioMed Central

155. Iwasaki M, Saito J, Zhao H, Sakamoto A, Hirota K, Ma D (2020) Inflammation triggered by sars-cov- 2 and ace 2 augment drives multiple organ failure of severe covid-19. Molecular mechanisms and implications. Inflammation 1-22

156. Wu C, Chen X, Cai Y, Zhou X, Xu S, Huang H, Zhang L, Zhou X, Du C, Zhang Y, Song J (2020) Risk factors associated with acute respiratory distress syndrome and death in patients with coronavirus disease 2019 pneumonia in Wuhan, China. JAMA Internal Med 180(7):934-43

157. Gibson PG, Qin L, Puah SH (2020) COVID-19 acute respiratory distress syndrome (ARDS): clinical features and differences from typical pre-COVID-19 ARDS. Med J Aust 213(2):54-56

158. Levi M, Van der Poll T, Ten Cate H, Van Deventer S (1997) The cytokine-mediated imbalance between coagulant and anticoagulant mechanisms in sepsis and endotoxaemia. Eur J Clin Invest 27(1):3-9

159. Zhang X, Hinton DR, Cua DJ, Stohlman SA, Lai MM (1997) Expression of interferon- $\gamma$ by a coronavirus defective-interfering RNA vector and its effect on viral replication, spread, and pathogenicity. Virology 233(2):327-338

160. Cunningham A, Beristain-Covarrubias N, Perez-Toledo M, Henderson I, Thomas M, Watson SP (2019) Understanding infectioninduced thrombosis: lessons learned from animal models. Front Immunol 10:2569

161. Channappanavar R, Perlman S (2017) Pathogenic human coronavirus infections: causes and consequences of cytokine storm and immunopathology. Seminars in immunopathology. Springer, pp 529-539

162. Java A, Apicelli AJ, Liszewski MK, Coler-Reilly A, Atkinson JP, Kim AH, Kulkarni HS (2020) The complement system in COVID-19: friend and foe? JCI insight 5(15):140

163. Fletcher-Sandersjöö A, Bellander BM (2020) Is COVID-19 associated thrombosis caused by overactivation of the complement cascade? A literature review. Thromb Res 194:36-41

164. Sarma JV, Ward PA (2011) The complement system. Cell Tissue Res 343(1):227-235

165. Keragala CB, Draxler DF, McQuilten ZK, Medcalf RL (2018) Haemostasis and innate immunity - a complementary relationship: a review of the intricate relationship between coagulation and complement pathways. Br J Haematol 180(6):782-798

166. Xu P, Zhou Q, Xu J (2020) Mechanism of thrombocytopenia in COVID-19 patients. Ann Hematol 99(6):1205-12508

167. Morrell CN, Aggrey AA, Chapman LM, Modjeski KL (2014) Emerging roles for platelets as immune and inflammatory cells. Blood. J Am Soc Hematol 123(18):2759-2767

168. Lefrançais E, Ortiz-Muñoz G, Caudrillier A, Mallavia B, Liu F, Sayah DM, Thornton EE, Headley MB, David T, Coughlin SR (2017) The lung is a site of platelet biogenesis and a reservoir for haematopoietic progenitors. Nature 544(7648):105-109

169. Walsh PN Platelet coagulation-protein interactions. In: Seminars in thrombosis and hemostasis, 2004. Copyright $\odot 2004$ by Thieme Medical Publishers, Inc., New York, pp 461-471

170. Yeager CL, Ashmun RA, Williams RK, Cardellichio CB, Shapiro LH, Look AT, Holmes KV (1992) Human aminopeptidase $\mathrm{N}$ is a receptor for human coronavirus 229E. Nature 357(6377):420-422

171. Bhotla HK, Kaul T, Balasubramanian B, Easwaran M, Arumugam VA, Pappusamy M, Muthupandian S, Meyyazhagan A (2020) Platelets to surrogate lung inflammation in COVID-19 patients. Med Hypotheses 143:110098

172. Biancardi VC, Stranahan AM, Krause EG, de Kloet AD, Stern JE (2016) Cross talk between AT1 receptors and Toll-like receptor 4 in microglia contributes to angiotensin II-derived ROS production in the hypothalamic paraventricular nucleus. Am J Physiol Heart Circ Physiol 310(3):H404-H415

173. Cognasse F, Nguyen KA, Damien P, McNicol A, Pozzetto B, Hamzeh-Cognasse H, Garraud O (2015) The inflammatory role of platelets via their TLRs and Siglec receptors. Front Immunol 6:83

174. Zhang S, Liu Y, Wang X, Yang L, Li H, Wang Y, Liu M, Zhao X, Xie Y, Yang Y (2020) SARS-CoV-2 binds platelet ACE2 to enhance thrombosis in COVID-19. J Hematol Oncol 13(1):1-22 
175. Manne BK, Denorme F, Middleton EA, Portier I, Rowley JW, Stubben CJ et al (2020) Platelet gene expression and function in patients with COVID-19. Blood 136:1317-1329

176. Shen S, Zhang J, Fang Y et al (2021) SARS-CoV-2 interacts with platelets and megakaryocytes via ACE2-independent mechanism. J Hematol Oncol 14:72. https://doi.org/10.1186/ s13045-021-01082-6

177. Fujimura Y, Titani K, Usami Y, Suzuki M, Oyama R, Matsui T, Fukui H, Sugimoto M, Ruggeri ZM (1991) Isolation and chemical characterization of two structurally and functionally distinct forms of botrocetin, the platelet coagglutinin isolated from the venom of Bothrops jararaca. Biochemistry 30(7):1957-1964

178. Hamako J, Matsui T, Suzuki M, Ito M, Makita K, Fujimura Y, Ozeki Y, Titani K (1996) Purification and characterization of bitiscetin, a novel von Willebrand factor modulator protein frombitis arietanssnake venom. Biochem Biophys Res Commun 226(1):273-279

179. Chanda C, Sarkar A, Sistla S, Chakrabarty D (2013) Anti-platelet activity of a three-finger toxin (3FTx) from Indian monocled cobra (Naja kaouthia) venom. Biochem Biophys Res Commun 441(3):550-554

180. Chérifi F, Laraba-Djebari F (2013) Isolated biomolecules of pharmacological interest in hemostasis from Cerastes cerastes venom. Journal of Venomous Animals and Toxins including Tropical Diseases 19(1):11

181. Peng H, Carretero OA, Vuljaj N, Liao TD, Motivala A, Peterson EL, Rhaleb NE (2005) Angiotensin-converting enzyme inhibitors. A new mechanism of action. Circulation 112:2436-2445

182. Stepensky D (2018) Pharmacokinetics of toxin-derived peptide drugs. Toxins 10(11):483

183. Smith CG, Vane JR (2003) The discovery of captopril. FASEB J 17(8):788-789

184. McCleary RJ, Kang TS, Kini RM (2015) Reptile venoms as a platform for drug development. Venoms to Drugs: Venom as a Source for the Development of Human Therapeutics. The Royal Society of Chemistry: Cambridge, pp 129-162

185. Gouda AS, Mégarbane B (2021) Snake venom-derived bradykinin-potentiating peptides: a promising therapy for COVID-19? Drug Dev Res 82(1):38-48

186. Lazarovici P, Marcinkiewicz C, Lelkes PI (2019) From snake venom's disintegrins and C-type lectins to anti-platelet drugs. Toxins 11(5):303

187. Huang T, Holt J, Lukasiewicz H, Niewiarowski S (1987) Trigramin. A low molecular weight peptide inhibiting fibrinogen interaction with platelet receptors expressed on glycoprotein IIbIIIa complex. J Biol Chem 262(33):16157-16163

188. Gan Z, Gould R, Jacobs JW, Friedman P, Polokoff M (1988) Echistatin A potent platelet aggregation inhibitor from the venom of the viper, Echis carinatus. J Biol Chem 263(36):19827-19832

189. Scarborough RM (1999) Development of eptifibatide. Am Heart J 138(6):1093-1104

190. Tcheng JE, O'Shea JC (2002) Eptifibatide: a potent inhibitor of the platelet receptor integrin glycoprotein IIb/IIIa. Expert Opin Pharmacother 3(8):1199-1210

191. Curran MP, Keating GM (2005) Eptifibatide. Drugs 65(14):2009-2035

192. Vu TT, Stafford AR, Leslie BA, Kim PY, Fredenburgh JC, Weitz JI (2013) Batroxobin binds fibrin with higher affinity and promotes clot expansion to a greater extent than thrombin. J Biol Chem 288(23):16862-16871

193. Earl ST, Masci PP, de Jersey J, Lavin MF, Dixon J (2012) Drug development from Australian elapid snake venoms and the Venomics pipeline of candidates for haemostasis: Textilinin-1 (Q8008), Haempatch ${ }^{\mathrm{TM}}(\mathrm{Q} 8009)$ and CoVase ${ }^{\mathrm{TM}}$ (V0801). Toxiconomy 59(4):456-463
194. Funk C, Gmür J, Herold R, Straub P (1971) Reptilase ${ }^{\circledR}-\mathrm{R}-\mathrm{a}$ new reagent in blood coagulation. Br J Haematol 21(1):43-52

195. Francischetti IM, Gil MR (2019) Diagnostic use of venoms. In: Transfusion medicine and hemostasis. Elsevier, Amsterdam, pp 969-975

196. Tokunaga F, Nagasawa K, Tamura S, Miyata T, Iwanaga S, Kisiel W (1988) The factor V-activating enzyme (RVV-V) from Russell's viper venom Identification of isoproteins RVV-V alpha,-V beta, and- $\mathrm{V}$ gamma and their complete amino acid sequences. $\mathrm{J}$ Biol Chem 263(33):17471-17481

197. Favaloro EJ, Wong RC (2014) Antiphospholipid antibody testing for the antiphospholipid syndrome: a comprehensive practical review including a synopsis of challenges and recent guidelines. Pathology 46(6):481-495

198. Morita T (2005) Structures and functions of snake venom CLPs (C-type lectin-like proteins) with anticoagulant-, procoagulant-, and platelet-modulating activities. ToxiconOMY 45(8):1099-1114

199. Braud S, Bon C, Wisner A (2000) Snake venom proteins acting on hemostasis. Biochimie 82(9-10):851-859

200. Beeton C (2013) Targets and therapeutic properties. Handbook of biologically active peptides. Elsevier, Amsterdam, pp 473-482

201. Utkin YN (2019) Last decade update for three-finger toxins: Newly emerging structures and biological activities. World J Biol Chem 10(1):17

202. Ameziani M, Chérifi F, Kiheli H, Saoud S, Hariti G, KellouTaîri S, Laraba-Djebari F (2020) Isolation and Functional Identification of an Antiplatelet RGD-Containing Disintegrin from Cerastes cerastes Venom. Protein J 39(5):574-590

203. Drugs.com (2020) Search. https://www.drugs.com/. Accessed 25 June 2020

204. Plateltex SRO (2018) Plateltex-biologicals, clinical use, information sheet (Prague, Czech Republic). https://www.plateltex. com/. Accessed 19 April 2018

205. A/S. V (2018) Vivostat autologous fibrin sealant (Medicon Valley: Scandinavia). https://www.vivostat.com/products/vivostatfibrin-sealant. Accessed 19 April 2018

206. Mazzucco L, Balbo V, Cattana E, Borzini P (2008) Platelet-rich plasma and platelet gel preparation using Plateltex®. Vox Sang 94(3):202-208

207. Plateltex SRO (2016) Device for the activation (gelification) of blood components destined to the topical non-transfusional use (Czech Republic: Praha). http://www.plateltex.com/data/pdf/ IFU4.3plateltexACTJUNE2016ENG.pdf. Accessed 19 March 2020

208. Marsh N, Williams V (2005) Practical applications of snake venom toxins in haemostasis. Toxiconomy 45(8):1171-1181

209. Illig KA, Ouriel K, DeWeese JA, Riggs P, Green RM (1996) Increasing the sensitivity of the diagnosis of chronic venous obstruction. J Vasc Surg 24(1):176-178

210. Stocker K, Fischer H, Meier J (1988) Practical application of the protein $\mathrm{C}$ activator Protac from Agkistrodon contortrix venom. Folia Haematol (Leipzig, Germany: 1928) 115(3):260-264

211. Fatah C, Samah S, Fatima LD (2018) Antiplatelet and anticoagulant activities of two phospholipase A2s purified from Cerastes cerastes venom: structure-function relationship. J Biochem Mol Toxicol 32(12):e22219

212. Chang L-s, Chung C, Huang H-B, Lin S-r (2001) Purification and characterization of a chymotrypsin inhibitor from the venom of Ophiophagus hannah (King Cobra). Biochem Biophys Res Commun 283(4):862-867

213. Yuan C-H, He Q-Y, Peng K, Diao J-B, Jiang L-P, Tang X, Liang S-P (2008) Discovery of a distinct superfamily of Kunitz-type toxin (KTT) from tarantulas. PLoS ONE 3(10):e3414 
214. Župunski V, Kordiš D, Gubenšek F (2003) Adaptive evolution in the snake venom Kunitz/BPTI protein family. FEBS Lett 547(1-3):131-136

215. Verheij HM, Boffa MC, Rothen C, Bryckaert MC, Verger R, de Haas GH (1980) Correlation of enzymatic activity and anticoagulant properties of phospholipase A2. Eur J Biochem 112(1):25-32

216. Evans HJ, Franson R, Qureshi G, Moo-Penn W (1980) Isolation of anticoagulant proteins from cobra venom (Naja nigricollis). Identity with phospholipases A2. J Biol Chem 255(8):3793-3797

217. Stefansson S, Kini RM, Evans HJ (1990) The basic phospholipase A2 from Naja nigricollis venom inhibits the prothrombinase complex by a novel nonenzymic mechanism. Biochemistry 29(33):7742-7746

218. Kini RM, Evans HJ (1995) The role of enzymatic activity in inhibition of the extrinsic tenase complex by phospholipase A2 isoenzymes from Naja nigricollis venom. Toxiconomy 33(12):1585-1590

219. Ouyang C, Teng C-M (1972) Purification and properties of the anticoagulant principle of Agkistrodon acutus venom. Biochim Biophys Acta BBA 278(1):155-162

220. Ouyang C, Yang F-Y (1975) Purification and properties of the anticoagulant principle of Trimeresurus gramineus venom. Biochim Biophys Acta BBA 386(2):479-492

221. Atoda H, Hyuga M, Morita T (1991) The primary structure of coagulation factor IX/factor X-binding protein isolated from the venom of Trimeresurus flavoviridis. Homology with asialoglycoprotein receptors, proteoglycan core protein, tetranectin, and lymphocyte Fc epsilon receptor for immunoglobulin E. J Biol Chem 266(23):14903-14911

222. Atoda H, Morita T (1993) Articles. J Biochem 113(2):159-163

223. Kini R, Stefansson S, Evans H (1988) NOn-phospholipase anticoagulants from Naja-nigricollis venom. In: Toxicon. PergamonElsevier Science Ltd The Boulevard, Langford Lane, pp 28-28

224. Kini RM, Haar NC, Evans HJ (1988) Non-enzymatic inhibitors of coagulation and platelet aggregation from Najanigricollis venom are cardiotoxins. Biochem Biophys Res Commun 150(3):1012-1016

225. Kini RM, Evans HJ (1988) Mechanism of platelet effects of cardiotoxins from Naja nigricollis crawshawii (spitting cobra) snake venom. Thromb Res 52(3):185-195

226. Mitra J, Bhattacharyya D (2014) Phosphodiesterase from Daboia russelli russelli venom: purification, partial characterization and inhibition of platelet aggregation. Toxiconomy 88:1-10

227. Trummal K, Aaspõllu A, Tõnismägi K, Samel M, Subbi J, Siigur J, Siigur E (2014) Phosphodiesterase from Vipera lebetina venom-structure and characterization. Biochimie 106:48-55

228. Kiheli H, Chérifi F, Ameziani M, Saoud S, Hariti G, LarabaDjebari F (2021) Isolation and characterization of CD39-like phosphodiesterase (Cc-PDE) from Cerastes cerastes venom: molecular inhibitory mechanism of antiaggregation and anticoagulation. Protein Pept Lett 28(4):426-441

229. Chen X (2010) YU X-d, DENG M, LI H, HE Q-y, LIU J-p (2008) Purification and Characterization of 5'-nucleotidase from Trimeresurus albolabris Venom. Appl Biochem Biotechnol 160(1):129-39. https://doi.org/10.1007/s12010-009-8673-1

230. Aster RH, Curtis BR, McFarland JG, Bougie DW (2009) Druginduced immune thrombocytopenia: pathogenesis, diagnosis, and management. J Thromb Haemost 7(6):911-918

231. Hanna EB, Rao SV, Manoukian SV, Saucedo JF (2010) The evolving role of Glycoprotein IIb/IIIa inhibitors in the setting of percutaneous coronary intervention: strategies to minimize bleeding risk and optimize outcomes. JACC 3(12):1209-1219

232. Al-Saleh SS, Khan SU, Ashraf M (2009) Biochemical characterization and some biological properties of the phosphodiesterase I purified from Agistrodon bilineatus venom
233. Mori N, Nikai T, Sugihara H (1987) Phosphodiesterase from the venom of Crotalus ruber ruber. Int J Biochem 19(2):115-119

234. Santoro ML, Vaquero TS, Leme AFP, Serrano SM (2009) NPPBJ, a nucleotide pyrophosphatase/phosphodiesterase from Bothrops jararaca snake venom, inhibits platelet aggregation. Toxiconomy 54(4):499-512

235. Sohn Y-D, Hong S-Y, Cho K-S, Choi W-S, Song S-W, Bae J-S, Kim D-S, Chung K-H (2008) Acute and repeated dose toxicity studies of recombinant saxatilin, a disintegrin from the Korean snake (Gloydius saxatilis). Toxiconomy 51(3):406-417

236. Wermelinger LS, Geraldo RB, Frattani FS, Rodrigues CR, Juliano MA, Castro HC, Zingali RB (2009) Integrin inhibitors from snake venom: exploring the relationship between the structure and activity of RGD-peptides. Arch Biochem Biophys 482(1-2):25-32

237. Oyama E, Takahashi H, Ishii K (2017) Effect of amino acids near the RGD sequence on binding activities between $\alpha \operatorname{IIb} \beta 3$ integrin and fibrinogen in the presence of RGD-containing synthetic peptides from elegantin and angustatin. Peptides 96:31-37

238. Ramos O, Selistre-de-Araujo H (2006) Snake venom metalloproteases - structure and function of catalytic and disintegrin domains. Comp Biochem Physiol C 142(3-4):328-346

239. Yamada T, Kidera A (1996) Tailoring echistatin to possess higher affinity for integrin $\alpha$ IIb $\beta$ 3. FEBS Lett 387(1):11-15

240. Hayashi Y, Katada J, Sato Y, Igarashi K, Takiguchi Y, Harada T, Muramatsu M, Yasuda E, Uno I (1998) Discovery and structureactivity relationship studies of a novel and specific peptide motif, Pro-XXX-Asp-X, as a platelet fibrinogen receptor antagonist. Bioorg Med Chem 6(3):355-364

241. Allane D, Oussedik-Oumehdi H, Harrat Z, Seve M, Laraba-Djebari F (2018) Isolation and characterization of an anti-leishmanial disintegrin from Cerastes cerastes venom. J Biochem Mol Toxicol 32(2):e22018

242. Sutcliffe MJ, Jaseja M, Hyde EI, Lu X, Williams JA (1994) Three-dimensional structure of the RGD-containing neurotoxin homologue dendroaspin. Nat Struct Biol 1(11):802-807

243. Williams JA, Lu X, Rahman S, Keating C, Kakkar V (1993) Dendroaspin: a potent integrin receptor inhibitor from the venoms of Dendroaspis viridis and D. jamesonii. Portland Press Ltd.,

244. Reese JA, Li X, Hauben M, Aster RH, Bougie DW, Curtis BR, George JN, Vesely SK (2010) Identifying drugs that cause acute thrombocytopenia: an analysis using 3 distinct methods. Blood 116(12):2127-2133

245. Jasti J, Paramasivam M, Srinivasan A, Singh T (2004) Crystal structure of echicetin from Echis carinatus (Indian saw-scaled viper) at $2.4 \AA$ resolution. J Mol Biol 335(1):167-176

246. Chen Y-L, Tsai K-W, Chang T, Hong T-M, Tsai I-H (2000) Glycoprotein Ib-binding protein from the venom of Deinagkistrodon acutus-cDNA sequence, functional characterization, and three-dimensional modeling. Thromb Haemostasis Stuttgart 83(1):119-126

247. Shin Y, Okuyama I, Hasegawa J, Morita T (2000) Molecular cloning of glycoprotein Ib-binding protein, flavocetin-A, which inhibits platelet aggregation. Thromb Res 99(3):239-247

248. Li TT, Fan ML, Hou SX, Li XY, Barry DM, Jin H, Luo SY, Kong F, Lau LF, Dai XR (2015) A novel snake venom-derived GPIb antagonist, anfibatide, protects mice from acute experimental ischaemic stroke and reperfusion injury. Br J Pharmacol 172(15):3904-3916

249. Kini RM, Evans HJ (1992) Structural domains in venom proteins: evidence that metalloproteinases and nonenzymatic platelet aggregation inhibitors (disintegrins) from snake venoms are derived by proteolysis from a common precursor. Toxiconomy 30(3):265-293 
250. Liu C-Z, Peng H-C, Huang T-F (1995) Crotavirin, a potent platelet aggregation inhibitor purified from the venom of the snake Crotalus viridis. Toxiconomy 33(10):1289-1298

251. Swaim M, Chiang H-S, Huang T-F (1996) Characterisation of platelet aggregation induced by PC-3 human prostate adenocarcinoma cells and inhibited by venom peptides, trigramin and rhodostomin. Eur J Cancer 32(4):715-721

252. Knight LC, Romano JE (2005) Functional expression of bitistatin, a disintegrin with potential use in molecular imaging of thromboembolic disease. Protein Expr Purif 39(2):307-319

253. Juárez P, Comas I, González-Candelas F, Calvete JJ (2008) Evolution of snake venom disintegrins by positive Darwinian selection. Mol Biol Evol 25(11):2391-2407

254. Wang R, Kini RM, Chung MC (1999) Rhodocetin, a novel platelet aggregation inhibitor from the venom of Calloselasma rhodostoma (Malayan pit viper): synergistic and noncovalent interaction between its subunits. Biochemistry 38(23):7584-7593

255. Paaventhan P, Kong C, Joseph JS, Chung MC, Kolatkar PR (2005) Structure of rhodocetin reveals noncovalently bound heterodimer interface. Protein Sci 14(1):169-175

256. Dörmann D, Clemetson JM, Navdaev A, Kehrel BE, Clemetson KJ (2001) Alboaggregin A activates platelets by a mechanism involving glycoprotein VI as well as glycoprotein Ib. Blood 97(4):929-936

257. Du X-Y, Clemetson JM, Navdaev A, Magnenat EM, Wells TN, Clemetson KJ (2002) Ophioluxin, a convulxin-like C-type lectin from Ophiophagus hannah (King cobra) is a powerful platelet activator via glycoprotein VI. J Biol Chem 277(38):35124-35132

258. Du X-Y, Magnenat E, Wells TN, Clemetson KJ (2002) Alboluxin, a snake C-type lectin from Trimeresurus albolabris venom is a potent platelet agonist acting via GPIb and GPVI. Thromb Haemost 87(04):692-698

259. Du X-Y, Navdaev A, Clemetson JM, Magnenat E, Wells TN, Clemetson KJ (2001) Bilinexin, a snake C-type lectin from Agkistrodon bilineatus venom agglutinates platelets via $\mathrm{GPIb}$ and $\alpha 2 \beta 1$. Thromb Haemost 86(11):1277-1283

260. Wijeyewickrema LC, Gardiner EE, Moroi M, Berndt MC, Andrews RK (2007) Snake venom metalloproteinases, crotarhagin and alborhagin, induce ectodomain shedding of the platelet collagen receptor, glycoprotein VI. Thromb Haemost 98(12):1285-1290

261. Oliveira LS, Estevão-Costa MI, Alvarenga VG, Vivas-Ruiz DE, Yarleque A, Lima AM, Cavaco A, Eble JA, Sanchez EF (2019) Atroxlysin-III, A Metalloproteinase from the Venom of the Peruvian Pit Viper Snake Bothrops atrox (Jergón) Induces Glycoprotein VI Shedding and Impairs Platelet Function. Molecules 24(19):3489

262. Monteiro RQ, Zingali RB (2000) Inhibition of prothrombin activation by bothrojaracin, a C-type lectin from Bothrops jararaca venom. Arch Biochem Biophys 382(1):123-128

263. Djebari FL, Martin-Eauclaire MF (1990) Purification and characterization of a phospholipase A2 from Cerastes cerastes (horn viper) snake venom. Toxiconomy 28(6):637-646

264. Cherifi F, Laraba-Djebari F (2016) CC3-SPase: a multifunctional thrombin-like protein from Cerastes cerastes venom with blood-clotting effect in human deficient plasma, interacting with fibrinogen and platelet receptors. J Biol Chem 287:9200e9212

265. Cherifi F, Saoud S, Laraba-Djebari F (2018) Exploration of the antithrombotic effect of a $\mathrm{C}$ type lectin purified from Cerastes cerastes venom by protein-protein docking. Med Technol J 2(2):226-227

266. Chérifi F, Saoud S, Laraba-Djebari F (2018) Molecular modeling, biochemical characterization, and pharmacological properties of Cc3-SPase: a platelet-aggregating thrombin-like enzyme purified from Cerastes cerastes venom. J Biochem Mol Toxicol 32(7):e22165
267. Shieh T-C, Kawabata S-i, Kihara H, Ohno M, Iwanaga S (1988) Amino acid sequence of a coagulant enzyme, flavoxobin, from Trimeresurus flavoviridis venom. J Biochem 103(4):596-605

268. Stocker KF (1990) Medical use of snake venom proteins. CRC Press, Boca Raton

269. Kornalik F (1985) The influence of snake venom enzymes on blood coagulation. Pharmacol Ther 29(3):353-405

270. Marrakchi N, Barbouche R, Guermazi S, Karoui H, Bon C, El Ayeb M (1997) Cerastotin, a serine protease from cerastes cerastes venom, with platelet-aggregating and agglutinating properties. Eur J Biochem 247(1):121-128

271. Silva-Junior FP, Guedes HL, Garvey LC, Aguiar AS, Bourguignon SC, Di Cera E, Giovanni-De-Simone S (2007) BJ-48, a novel thrombin-like enzyme from the Bothrops jararacussu venom with high selectivity for Arg over Lys in P1: role of N-glycosylation in thermostability and active site accessibility. Toxiconomy 50(1):18-31

272. Magalhães A, Magalhães HP, Richardson M, Gontijo S, Ferreira RN, Almeida AP, Sanchez EF (2007) Purification and properties of a coagulant thrombin-like enzyme from the venom of Bothrops leucurus. Comp Biochem Physiol A 146(4):565-575

273. Sant'Ana C, Ticli F, Oliveira L, Giglio J, Rechia C, Fuly A (2008) Selistre de Araujo, HS; Franco, JJ; Stabeli, RG; Soares, AM; Sampaio, SV BjussuSP-I: a new thrombinlike enzyme isolated from Bothrops jararacussu snake venom. Comp Biochem Physiol A $151(3): 443-454$

274. Tang S-S, Zhang J-H, Tang B-S, Tang Z-H, Li H-Z, Yuan H-J, Chui S-L, Zhao E-Y (2009) Biochemical and hemostatic mechanism of a novel thrombin-like enzyme. Thromb Res 124(5):631-639

275. Tan NH (2010) Isolation and characterization of the thrombinlike enzyme from Cryptelytrops purpureomaculatus venom. Comp Biochem Physiol C: Toxicol Pharmacol 151(1):131-136

276. Pirkle H, Markland FS, Theodor I, Baumgartner R, Bajwa SS, Kirakossian H (1981) The primary structure of crotalase, a thrombin-like venom enzyme, exhibits closer homology to kallikrein than to other serine proteases. Biochem Biophys Res Commun 99(2):715-721

277. Pirkle H, Theodor I, Miyada D, Simmons G (1986) Thrombinlike enzyme from the venom of Bitis gabonica. Purification, properties, and coagulant actions. J Biol Chem 261(19):8830-8835

278. Farid TM, Tu AT, El-Asmar MF (1989) Characterization of cerastobin, a thrombin-like enzyme from the venom of Cerastes vipera (Sahara sand viper). Biochemistry 28(1):371-377

279. PhD GPS, Md DBM, ScD GRW, Md DEL (2002) Cost-effectiveness of ancrod treatment of acute ischaemic stroke: results from the Stroke Treatment with Ancrod Trial (STAT). J Eval Clin Pract 8(1):61-70

280. Lapikova E, Drozd N, Tolstenkov A, Makarov V, Zvyagintseva T, Shevchenko N, Bakunina I, Besednova N, Kuznetsova T (2008) Inhibition of thrombin and factor Xa by Fucus evanescens fucoidan and its modified analogs. Bull Exp Biol Med 146(3):328-333

281. Girish VM, Kini RM (2016) Exactin: a specific inhibitor of Factor $\mathrm{X}$ activation by extrinsic tenase complex from the venom of Hemachatus haemachatus. Sci Rep 6:32036

282. Barnwal B, Jobichen C, Girish VM, Foo CS, Sivaraman J, Kini RM (2016) Ringhalexin from Hemachatus haemachatus: a novel inhibitor of extrinsic tenase complex. Sci Rep 6:25935

283. Choudhury M, McCleary RJ, Kini RM, Velmurugan D (2018) Orphan Three-Finger Toxins Bind at Tissue Factor-Factor VIIa interface to inhibit factor $\mathrm{X}$ activation: identification of functional site by docking. TH Open 2(3):e303

284. Banerjee Y, Mizuguchi J, Iwanaga S, Kini RM (2005) Hemextin $\mathrm{AB}$ complex, a unique anticoagulant protein complex from Hemachatus haemachatus (African Ringhals cobra) venom that 
inhibits clot initiation and factor VIIa activity. J Biol Chem 280(52):42601-42611

285. Cecilio AB, Caldas S, Oliveira RAD, Santos AS, Richardson M, Naumann GB, Schneider FS, Alvarenga VG, Estevão-Costa MI, Fuly AL (2013) Molecular characterization of Lys49 and Asp49 phospholipases A2 from snake venom and their antiviral activities against Dengue virus. Toxins 5(10):1780-1798

286. Tripathy S, Dassarma B, Roy S, Chabalala H, Matsabisa MG (2020) A review on possible modes of actions of Chloroquine/ Hydroxychloroquine: repurposing against SAR-COV-2 (COVID 19) pandemic. Int J Antimicrob Agents 56(2):106028

287. Warren TK, Jordan R, Lo MK, Ray AS, Mackman RL, Soloveva V, Siegel D, Perron M, Bannister R, Hui HC (2016) Therapeutic efficacy of the small molecule GS-5734 against Ebola virus in rhesus monkeys. Nature 531(7594):381-385

288. Borkow G, Ovadia M (1999) Selective lysis of virus-infected cells by cobra snake cytotoxins: A sendai virus, human erythrocytes, and cytotoxin model. Biochem Biophys Res Commun 264(1):63-68

289. Muller VDM, Russo RR, Cintra ACO, Sartim MA, Alves-Paiva RDM, Figueiredo LTM, Sampaio SV, Aquino VH (2012) Crotoxin and phospholipases A2 from Crotalus durissus terrificus showed antiviral activity against dengue and yellow fever viruses. Toxicon 59(4):507-515
290. Pai VB, Nahata MC (1999) Nelfinavir mesylate: a protease inhibitor. Ann Pharmacother 33(3):325-339

291. Villarrubia VG, Costa LA, Díez RA (2004) Fosfolipasas A2 segregadas (sPLA2):¿ amigas o enemigas? ¿ Actores de la resistencia antibacteriana y antivirus de la inmunodeficiencia humana? Med Clin 123(19):749-757

292. Freedberg DE, Conigliaro J, Wang TC, Tracey KJ, Callahan MV, Abrams JA, Sobieszczyk ME, Markowitz DD, Gupta A, O'Donnell MR (2020) Famotidine use is associated with improved clinical outcomes in hospitalized COVID-19 patients: A propensity score matched retrospective cohort study. Gastroenterology

293. Zhang Y-J, Wang J-H, Lee W-H, Wang Q, Liu H, Zheng Y-T, Zhang Y (2003) Molecular characterization of Trimeresurus stejnegeri venom L-amino acid oxidase with potential anti-HIV activity. Biochem Biophys Res Commun 309(3):598-604

294. Rivero J, de Castro F, Stival A, Magalhães M, Carmo Filho J, Pfrimer I (2011) Mechanisms of virus resistance and antiviral activity of snake venoms. Journal of Venomous Animals and Toxins including Tropical Diseases 17(4):387-393

Publisher's Note Springer Nature remains neutral with regard to jurisdictional claims in published maps and institutional affiliations. 